\title{
Rines E3 Ubiquitin Ligase Regulates MAO-A Levels and Emotional Responses
}

\author{
Miyuki Kabayama, ${ }^{1}$ Kazuto Sakoori, ${ }^{1}$ Kazuyuki Yamada, ${ }^{3}$ Veravej G. Ornthanalai, ${ }^{2}$ Maya Ota, ${ }^{1}$ Naoko Morimura, ${ }^{1}$ \\ Kei-ichi Katayama, ${ }^{1}$ Niall P. Murphy, ${ }^{2}$ and Jun Aruga ${ }^{1}$ \\ ${ }^{1}$ Laboratory for Behavioral and Developmental Disorders, ${ }^{2}$ Molecular Neuropathology Group, and ${ }^{3}$ Support Unit for Animal Resources Development, \\ RIKEN Brain Science Institute, Wako-shi, Saitama 351-0198, Japan
}

Monoamine oxidase A (MAO-A), the catabolic enzyme of norepinephrine and serotonin, plays a critical role in emotional and social behavior. However, the control and impact of endogenous MAO-A levels in the brain remains unknown. Here we show that the RING finger-type E3 ubiquitin ligase Rines/RNF180 regulates brain MAO-A subset, monoamine levels, and emotional behavior. Rines interacted with MAO-A and promoted its ubiquitination and degradation. Rines knock-out mice displayed impaired stress responses, enhanced anxiety, and affiliative behavior. Norepinephrine and serotonin levels were altered in the locus ceruleus, prefrontal cortex, and amygdala in either stressed or resting conditions, and MAO-A enzymatic activity was enhanced in the locus ceruleus in Rines knock-out mice. Treatment of Rines knock-out mice with MAO inhibitors showed genotype-specific effects on some of the abnormal affective behaviors. These results indicated that the control of emotional behavior by Rines is partly due to the regulation of MAO-A levels. These findings verify that Rines is a critical regulator of the monoaminergic system and emotional behavior and identify a promising candidate drug target for treating diseases associated with emotion.

\section{Introduction}

Mood and emotion are modulated by the brain monoamine transmitters norepinephrine (NE) and serotonin (5-HT), along with their essential catabolic enzyme monoamine oxidase A (MAO-A) (Shih et al., 1999). MAO-A has long been considered to be a central factor at the interface of psychiatry and pharmacology (Shih et al., 1999; Bortolato et al., 2008). MAO inhibitors and selective 5-HT or NE reuptake inhibitors are common pharmacotherapies for treating depression and anxiety disorders that work by increasing the levels of 5-HT and NE in the brain (Millan, 2003; Ravindran and Stein, 2010; Koen and Stein, 2011).

Consistent with the therapeutic importance of MAO-A, genetic evidence indicates that its expression levels in the brain may be a critical parameter for emotional and social behavior across species. Low-expression variants of MAO-A have been linked with increased risk of violent and aggressive behaviors (Hunter, 2010). A complete and selective deficiency of MAO-A was discovered in an extended family with a rare $\mathrm{X}$-linked genetic mutation; members of this family showed Brunner syndrome, a collection

\footnotetext{
Received Dec. 14, 2012; revised June 15, 2013; accepted June 21, 2013.

Author contributions: M.K., K.S., and J.A. designed research; M.K., K.S., K.Y., V.G.O., M.O., N.M., K.K., N.P.M., and J.A. performed research; M.K., K.S., K.Y., V.G.O., M.O., N.M., K.K., N.P.M., and J.A. analyzed data; M.K. and J.A. wrote the paper.

This study was supported by RIKEN Brain Science Institute funds and by a Ministry of Education, Culture, Sports, Science, and Technology, Japan Grant-in-Aid for Scientific Research A (Grant \#21240031). We thank Drs. Charles Yokoyama and Alexandra V. Terashima for helpful comments on the manuscript, Dr. Hiroshi Kawabe for technical advice and valuable discussion, and members of RIKEN Brain Science Institute Research Resources Center for assistance in animal maintenance and RT-PCR analysis.

The authors declare no competing financial interests.

Correspondence should be addressed to Jun Aruga, Laboratory for Behavioral and Developmental Disorders, RIKEN BSI, 2-1 Hirosawa, Wako-shi, Saitama 351-0198, Japan. E-mail: jaruga@brain.riken.jp.

DOI:10.1523/JNEUROSCI.5717-12.2013

Copyright $\odot 2013$ the authors $\quad 0270-6474 / 13 / 3312940-14 \$ 15.00 / 0$
}

of symptoms including impulsive aggression and antisocial behaviors (Brunner et al., 1993). In mice, male MAO-A knock-out (KO) mice exhibited enhanced aggression (Cases et al., 1995; Scott et al., 2008) and hypomorphic mutant mice were defective in social interactions (Cases et al., 1995; Scott et al., 2008; Bortolato et al., 2011). In contrast, promoter polymorphisms linked to high MAO-A activity are frequently observed in anxiety disorders and major depression in females (Deckert et al., 1999; Schulze et al., 2000; Samochowiec et al., 2004; Yu et al., 2005). In addition, MAO-A protein levels have been correlated with human emotional traits: a $34 \%$ increase in the brains of nonsmoking major-depression patients (Meyer et al., 2006) and an inverse correlation with the severity of antisocial traits (Alia-Klein et al., 2008). This evidence suggests that MAO-A levels need to be finely tuned for appropriate emotional responses.

We hypothesized that the ubiquitin proteasomal system (UPS) may have a vital role in MAO-A metabolism because UPS controls protein homeostasis for neuronal properties such as synaptic plasticity (Hershko and Ciechanover, 1998; Pickart, 2001; Johnston and Madura, 2004; Moriyoshi et al., 2004; Yao et al., 2007) and memory formation (Gong et al., 2006; Lee et al., 2008; Sakurai et al., 2008). E3 ubiquitin ligases play a key role in UPS function by determining the specificity and timing of ubiquitination and subsequent degradation of its substrates (Pickart, 2001). However, whether E3 ligases play a role in controlling emotional and social responses by modulating the monoamine levels is virtually unknown. In particular, the protein degradation mechanism that targets monoamine-metabolizing enzymes, including $\mathrm{MAO}$, in the brain is largely unknown, although MAO proteins are ubiquitinated in cell culture (Jiang et al., 2006), suggesting that the mechanism is mediated by UPS. 
Here we report the role of an E3 ligase, Rines, in monoamine control and in emotional and social behaviors. Analysis of Rines $\mathrm{KO}$ mice demonstrates that Rines controls $\mathrm{MAO}-\mathrm{A}$ protein and monoamine levels as well as emotional and social behaviors.

\section{Materials and Methods}

Animals. All animal experiments were performed according to the guidelines for animal experimentation at RIKEN. The mice were housed on a $12 \mathrm{~h}: 12 \mathrm{~h}$ light/dark cycle, with the dark cycle occurring from 20:00 to 8:00. All mice used were littermates from mated heterozygotes. All behavioral tests in this study were performed with adult male mice.

Generation of Rines mutant mice. Rines mutant mice were generated as described previously (Katayama et al., 2010). To construct the Rinestargeting vector, overlapping Rines genomic clones were isolated from a phage library derived from mice of the 129 SV strain (Stratagene). The targeting construct contained the 7.6 and $3 \mathrm{~kb}$ homology regions and the $11 \mathrm{~kb}$ fragment containing the exon 6 of Rines was replaced with the phosphoglycerol kinase (PGK) neoexpression cassette flanked by a loxP sequence. E14 embryonic stem cells were electroporated with the targeting construct and selected with G418. Drug-resistant clones were analyzed by Southern blotting. BglII-digested genomic DNA was hybridized with a $0.9 \mathrm{~kb} \mathrm{3}$ ' genomic fragment, which corresponded to the genomic sequence outside of the targeting vector and a $0.6 \mathrm{~kb}$ PstI PGK neoprobe, respectively. Chimeric mice were generated by the injection of targeted embryonic stem cells into C57BL/6J blastocysts. To excise the PGK neocassette, mice with germline transmission were first mated with transgenic mice expressing Cre recombinase under the control of the cytomegalovirus immediate early enhancer chicken $\beta$-actin hybrid promoter. Correct excision of the PGK neocassette was confirmed by Southern blot. Mice carrying the mutated Rines allele were backcrossed to C57BL/6J for more than six generations before analysis. Genotyping of progenies was performed by Southern blot or RT-PCR analysis of DNA isolated from brain samples. In all experiments using Rines mutant mice, the controls were sex-matched littermate wild-type (WT) mice.

Antibodies. A rabbit polyclonal antibody to Rines was raised against a GST fusion protein of mouse Rines (residues 1-150). An obtained antibody in antisera was purified by affinity chromatography with the GSTRines (residues 1-150). The following antibodies were obtained from commercial sources: MAO-A (T-19; Santa Cruz Biotechnology) for immunostaining; MAO-A IP-WB antibody pair (H00004128-PW1) for immunoprecipitation and immunoblotting; tyrosine hydroxylase $(\mathrm{TH}$; Millipore); ubiquitin-protein conjugate (Enzo Life Sciences); $\beta$-actin (Sigma); HA (Sigma or 12CA5; Roche); Flag (M2; Sigma); and Myc (9E10; Santa Cruz Biotechnology).

RNA extraction and RT-PCR. RNA extraction and RT-PCR were performed as described previously (Inoue et al., 2004). RNAs were isolated from mice brains with TRIzol reagent (Invitrogen). After DNaseI treatment, reverse transcription was performed with M-MLV reverse transcriptase (Invitrogen) or Superscript II reverse transcriptase (Invitrogen). G3PDH was evaluated to monitor RNA recovery. The PCR cycles, annealing temperature, and primer sequences were as follows: 22 cycles, $68^{\circ} \mathrm{C}$, mouse $(\mathrm{m})$ G3PDHF: $5^{\prime}$-TGTTCCTACCCCCAATGTGT-3'; mG3PDH reverse: $5^{\prime}$-TG TGAGGGAGATGCTCAGTG- $3^{\prime} ; 30$ cycles, $58^{\circ} \mathrm{C}$, mRines 1 forward: $5^{\prime}$-AT GAAAAGAAGCGAAGAGTCGACAAGTA-3', mRines 1 reverse: $5^{\prime}$-CGCG AATTCTCCTGAGTATTTACCCTGC- 3 ' , mRines 2 forward: $5^{\prime}$-CGCGGA TCCCTGATGGATCTGCCCTCAG-3', mRines 2 reverse: $5^{\prime}$-CGCGAATT CCATGTAGCTGTCCTTCTCC-3' ${ }^{\prime}$, mRines 3 forward: $5^{\prime}$-CGCGGATCCG CGACGTATTTTGAGATGA-3' ${ }^{\prime}$, mRines 3 reverse: $5^{\prime}$-CGCGAATTCGAA TGGCAGGCTGTTAGCG-3' ${ }^{\prime}$ mRines 4 forward: $5^{\prime}$-CGCGGATCCACTCT GCGAAGGCAGCAGA-3', mRines 4 reverse: 5' $^{\prime}$-CTAAAACGGAAAGAAA AAAATAGCAAAG- $3^{\prime}$.

To quantify Rines expression in whole brains (1- to 10-month-old WT mice) and brain punch regions (3-month-old WT mice), a quantitative real-time PCR system (ABI7900HT; Applied Biosystems) with TaqMan MGB (Applied Biosystems) was used. For quantification of Rines expression in brain punch regions, circular tissue punches were taken of the CA3 and dentate gyrus of the hippocampus, medial prefrontal cortex, basolateral and cortical nuclei of the amygdala, nucleus accumbens, cor- pus striatum, substantial nigra, raphe nuclei, and locus ceruleus (LC) using disposable biopsy needles (Biopsy Punch; Kai Medical) with diameters of $1,1,1,2,1.5,1.5,1.5,1.5$, and $2 \mathrm{~mm}$, respectively, from $150-\mu \mathrm{m}$ thick frozen coronal brain sections of 3-month-old male C57BL/6J mice. PCR was started at $95^{\circ} \mathrm{C}$ for $10 \mathrm{~min}$, followed by 50 cycles at $95^{\circ} \mathrm{C}$ for $15 \mathrm{~s}$ and $60^{\circ} \mathrm{C}$ for $60 \mathrm{~s}$. The intensity relative to GAPDH (4352339E; Applied Biosystems) was calculated and the relative amount of mRNA was plotted. The TaqMan Rines MGB probe was 5'-AGTGGACAGTTGGGAA A- $3^{\prime}$ and the Rines primer sequences were: forward: $5^{\prime}$-TCAGCTGCTT GCTGCAGAAG-3' and reverse: 5' -CCCCACAGAAAGGACAATTCA$3^{\prime}$. Real-time RT-PCR was used for quantification of MAO-A, MAO-B, DBH, NET, VMAT2, COMT, and Rines expression in the LC of WT and Rines KO mice using a Rotor-Gene Real-time PCR system (QIAGEN) with SYBR Green Real-time PCR Master Mix (Applied Biosystems). Circular tissue punches ( $1.5 \mathrm{~mm}$ in diameter) of the LC region were taken from 150- $\mu$ m-thick frozen coronal brain sections of 9-month-old mice ( $n=7$ per group). PCR was started at $95^{\circ} \mathrm{C}$ for $15 \mathrm{~min}$, followed by 40 cycles at $95^{\circ} \mathrm{C}$ for $10 \mathrm{~s}, 55^{\circ} \mathrm{C}$ for $20 \mathrm{~s}$, and $72^{\circ} \mathrm{C}$ for $20 \mathrm{~s}$. The amplification specificity was tested by a dissociation curve $\left(72-95^{\circ} \mathrm{C}\right)$. The intensity relative to G3PDH was calculated. The primer sequences were as follows: mRines forward: 5'-TTCCTGCGCTCTGCCAGCTTC-3', mRines reverse: 5' -TGTAGCCATCGTTCGCGCCT-3', mMAO-A forward: 5' -AA CGACTTGCTAAACTACAT-3' ${ }^{\prime}$, mMAO-A reverse: 5' -AGCAGAGAAG AGCCACAGAA-3' 'mMAO-Bforward:5' -GAAAACTGGTACGTCTCA CC-3', mMAO-B reverse: 5'-GAGCTGTTGCTGACAAGATG-3', mNET forward: 5'-TGGTTTTATGGTGTGGACAG-3', mNET reverse: 5'-GGTGCTCATTCTCCGGGGTG-3', mDBH forward: 5'-TGACGG GCAGGAAGGTGGTTAC-3', mDBH reverse: $5^{\prime}$-CTGGAAGTGGGG GCTGTAGTGG-3' ${ }^{\prime}$, mCOMT forward:5' -TGGCACAAAGGAGCAGCG CATC-3', mCOMT reverse: 5'-ACCCACGTTCATGGCCCACTC-3', mVMAT2 forward: 5' -AGCGCTCACAGCCTCCACTTC-3', mVMAT2 reverse: 5'-CGTGGCATTCCCCGTGAACAC-3', mG3PDH forward: 5' -TCCACCACCCTGTTGCTGTA- ${ }^{\prime}$ ', and mG3PDH reverse: 5' -ACCA CAGTCCATGCCATCAC-3'.

Subcellular fractionation. The mouse brain tissues were isolated and homogenized in a homogenization buffer ( $5 \mathrm{~mm}$ Tris- $\mathrm{HCl}, \mathrm{pH} 8.0,0.32 \mathrm{M}$ sucrose, $1 \mathrm{~mm}$ EDTA, $1 \mathrm{~mm}$ 2-mercaptoethanol, and complete protease inhibitor mixture; Roche). This homogenate was centrifuged at $1800 \times g$ for $10 \mathrm{~min}$ and the supernatant was further centrifuged at $10,000 \times g$ for $15 \mathrm{~min}$. Subsequently, the supernatant was centrifuged at 75,000 $\times g$ for $60 \mathrm{~min}$, after which time the pellet (microsome fraction) was resuspended in SDS lysis buffer (50 mM Tris-HCl, pH 7.5, 0.5 mm EDTA, 1\% SDS, and $1 \mathrm{~mm}$ dithiothreitol) and diluted 5-fold by adding $0.5 \% \mathrm{NP}-40$.

Behavioral tests. The mice were kept in isolation for at least 1 week before the behavioral experiments. The laboratory was air-conditioned, with the temperature and humidity maintained within $\sim 22-23^{\circ} \mathrm{C}$ and $50-55 \%$, respectively. The experiments were conducted during the light phase (11:00-17:30), except for the home cage activity and residentintruder tests. Male mice 4.5-8 months old (open field, elevated plus maze, light-dark box, passive avoidance, forced swimming, residentintruder, hidden cookie, hot plate, and tail-flick tests), 12 months old (social interaction test), or 2-3 months old (other behavioral tests) were used.

Open field test. The open-field test was performed as described previously (Sakatani et al., 2009). Each mouse was placed in the center of an open-field apparatus $(50 \times 50 \times 40[\mathrm{H}] \mathrm{cm})$ illuminated by lightemitting diodes (70 lux at the center of the field) and its horizontal movements were monitored for 15 min with a CCD camera. Distance traveled $(\mathrm{cm})$ and duration $(\mathrm{s})$ in the center area of the field $(36 \%$ of the field) were adopted as the indices. The relevant data were collected every minute and analyzed with Image OF4 software (O'Hara).

Elevated plus-maze test. The elevated plus-maze test was conducted as described previously (Satoh et al., 2007). Mice were tested for anxietylike behavior on a standard plus-maze apparatus (closed arms, $25 \times 5 \times$ $15[\mathrm{H}] \mathrm{cm}$; open arms, $25 \times 5 \times 0.3[\mathrm{H}] \mathrm{cm}$ arranged orthogonally) 60 $\mathrm{cm}$ above the floor. Illuminance was 70 lux at the center platform of the maze $(5 \times 5 \mathrm{~cm})$. Each mouse was placed on the center platform facing an open arm and then was allowed to move freely in the maze for $5 \mathrm{~min}$. Total distance traveled, percentage of time in the open arms, and per- 
centage of open arm entries were measured as indices. Data were collected and analyzed using ImageJ EPM software (O'Hara).

Light-dark box transition test. The light-dark box transition test was performed as described previously (Yamada et al., 2003). The apparatus consisted of a cage $(40 \times 20 \times 20 \mathrm{~cm})$ equally divided in two by a black partition containing a small opening. One chamber was open and brightly illuminated (250 lux), whereas the other was closed and dark. Mice were placed into the light side and allowed to move freely between the two chambers for $10 \mathrm{~min}$. Three parameters were measured with ImageJ LD software (O'Hara): latency to enter the light compartment, number of entries into the light compartment, and duration in the light compartment.

Passive avoidance test. The passive avoidance test was performed as described previously with slight modification (Yamada et al., 2003). A single mouse was introduced into a light compartment of a light-dark box (Muromachi-kikai). During habituation, $1 \mathrm{~min}$ after introduction, the sliding door between the light and dark compartments was opened and the mouse was allowed to freely explore the box for $4 \mathrm{~min}$ with the sliding door open and then returned to its home cage. For conditioning, which was performed $24 \mathrm{~h}$ after habituation, the mouse was introduced into the light compartment; 1 min after introduction, the sliding door was opened and when both hindlimbs of the mouse had entered the dark box, an electrical foot shock was delivered via the floor grid in the dark compartment $(0.2 \mathrm{~mA}$ for $3 \mathrm{~s}$ using a shock generator-scrambler; Muromachi-kikai). When the mouse had entered the light box, the sliding door was closed; the mouse was left in the light box for $2 \mathrm{~min}$ and then returned to its home cage. Testing was performed $24 \mathrm{~h}$ after conditioning by reintroducing the mouse into the light compartment of the light-dark box. The latency for the mouse to enter the dark compartment was measured (light-dark latency, with a 999 s cutoff).

Forced swimming test. The forced swimming test was performed as described previously with slight modification (Porsolt et al., 1978; Porsolt et al., 1979; Duncan et al., 1993). Each mouse was placed for $15 \mathrm{~min}$ in a glass cylinder ( $30 \mathrm{~cm}$ high, $10 \mathrm{~cm}$ in diameter) containing $10 \mathrm{~cm}$ of water maintained at $24-25^{\circ} \mathrm{C}$. After $24 \mathrm{~h}$, each mouse was replaced for 5 $\mathrm{min}$ in the glass cylinder with water. The time spent immobile on days 1 and 2 was recorded visually during the test period. In the forced swim test, immobility is induced in the test swim by previous exposure to the conditioning swim (Duncan et al., 1993).

Hot plate and tail flick tests. In the hot plate test, the surface of the hot plate (Ugo Basile) was heated to a constant temperature of $52 \pm 0.5^{\circ} \mathrm{C}$. Each mouse was placed on the hot plate, which was surrounded by a clear acrylic cage ( $18 \mathrm{~cm}$ high, $19 \mathrm{~cm}$ in diameter, open top). The latencies to respond with licking of the forepaws and flinching of the hindpaws were measured visually. The cutoff time was $60 \mathrm{~s}$. In the tail flick test, each mouse was individually restrained on the radiant heat meter (Ugo Basile) and focused heat was applied to the surface of the tail at a distance $2-3 \mathrm{~cm}$ from its tip. The latency to reflexive removal of the tail from the heat was recorded manually as the tail flick latency.

Social interaction test (encounter method). The social interaction test was performed as described previously (Kato et al., 2008). A subject mouse was individually placed at the center of a white-colored open field $(40 \times 40 \times 30[\mathrm{H}] \mathrm{cm})$. Immediately thereafter, a target mouse was also introduced into the same open field. The duration of contact behavior was then measured for $6 \mathrm{~h}$. Contact or separation was expressed as " 1 " or "2," respectively. That is, the software returned a value of " 1 " when the mice were in contact and a value of " 2 " when they were separated. Data were collected and analyzed using a personal computer and commercially available software (Time HC; O’Hara).

Resident-intruder test. The resident-intruder test was performed during the dark phase (21:00-23:00). The times spent in following, approaching, and sniffing the intruder mice (12-week-old male BALB/c mice housed in groups) were measured for $5 \mathrm{~min}$. The latency to the first attack, duration of fighting, and number of bouts of fighting were measured for $10 \mathrm{~min}$. Social behaviors were measured with video recordings by well trained observers who were blind to the genotypes.

Home cage activity. The spontaneous activity of mice in their home cage was measured using a 24-channel ABsystem 4.0 (Neuroscience). Cages were individually set into compartments made of stainless steel in

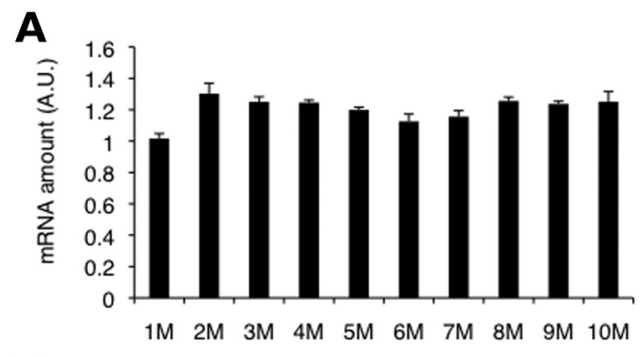

B

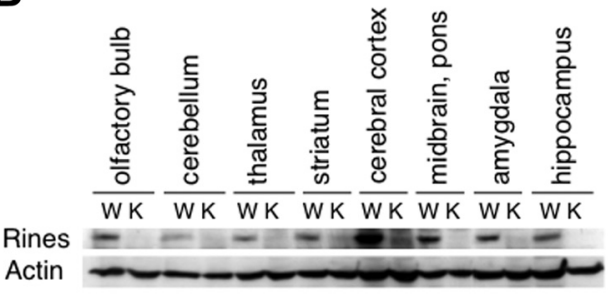

C

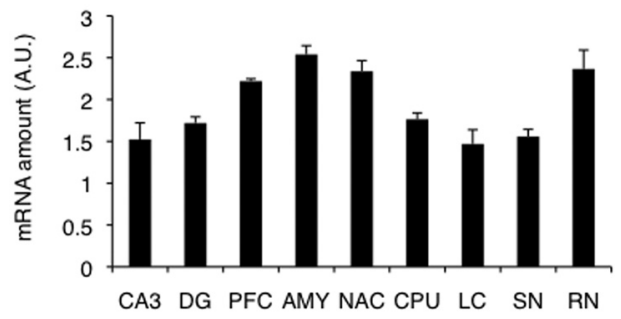

Figure 1. Rines expression in the mouse brain. $\boldsymbol{A}, \boldsymbol{C}$, Quantitative RT-PCR analysis. $\boldsymbol{A}$, Devel opmental changes in the Rines mRNA level in the brain from 1 to 10 months of age (M). $\boldsymbol{B}$, Distribution of the Rines protein in adult brain. Microsomal fractions from WT (W) and Rines KO (K) were subjected to immunoblotting analysis using anti-Rines and anti- $\beta$-actin antibodies. $C$, Regional expression of Rines in adult (12 weeks) brain. CA3 and DG, dentate gyrus of hippocampus; PFC, prefrontal cortex; AMY, amygdala; NAC, nucleus accumbens; CPU, corpus striatum; LC, locus ceruleus; $S N$, substantia nigra; $R N$, raphe nuclei; $A U$, arbitrary unit.

the negative breeding rack (JCL). An infrared sensor mounted on the ceiling of each compartment detected the movements of the mice. Home cage activity was measured for 1 week from the afternoon of the day of transfer to the behavioral laboratory (day 1 ) until the same day of the next week (day 8).

Hidden cookie test. The hidden cookie test was performed as described previously with slight modification (Irie et al., 2012). Mice first were habituated overnight to butter cookies in the home cage. The next day, the mice were food deprived for $24 \mathrm{~h}$. The test was conducted in a new cage. A piece of butter cookie $(0.75 \mathrm{mg})$ was placed at a randomly chosen area on the cage floor and then the entire cage floor was covered with corncob bedding to a depth of $4 \mathrm{~cm}$. The subject was placed into the cage and latency to find and eat the cookie was recorded.

Auditory startle response and prepulse inhibition tests. Each mouse was placed into a small cage for measuring the auditory startle response (30 or $35 \mathrm{~mm}$ in diameter, $12 \mathrm{~cm}$ long), after which the cage was set on a sensor block installed in a sound-proof chamber $(60 \times 50 \times 67[\mathrm{H}] \mathrm{cm})$. A dim light was mounted on the ceiling of the sound-proof chamber (10 lux at the center of the sensor block) and a $65 \mathrm{~dB}$ white noise was presented as background noise. In the auditory startle response test, mice were acclimated to the experimental condition for $5 \mathrm{~min}$, after which time the experimental session began. In the first session, 10 startle stimuli $(120 \mathrm{~dB}$, $40 \mathrm{~ms}$ ) were presented at random intertrial intervals (10-20 s). In the second session, the startle responses to stimuli of various intensities were assessed. White noise stimuli ranging in intensity from 70 to $120 \mathrm{~dB}(70$, $75,80,85,90,95,100,110$, and $120 \mathrm{~dB} ; 40 \mathrm{~ms}$ ) were presented 5 times each in quasirandom order at random intertrial intervals $(10-20 \mathrm{~s})$. In the prepulse inhibition session, the mice experienced five types of trials: no stimulus; startle stimulus $(120 \mathrm{~dB}, 40 \mathrm{~ms})$ alone; $70 \mathrm{~dB}$ prepulse $(20$ 
A

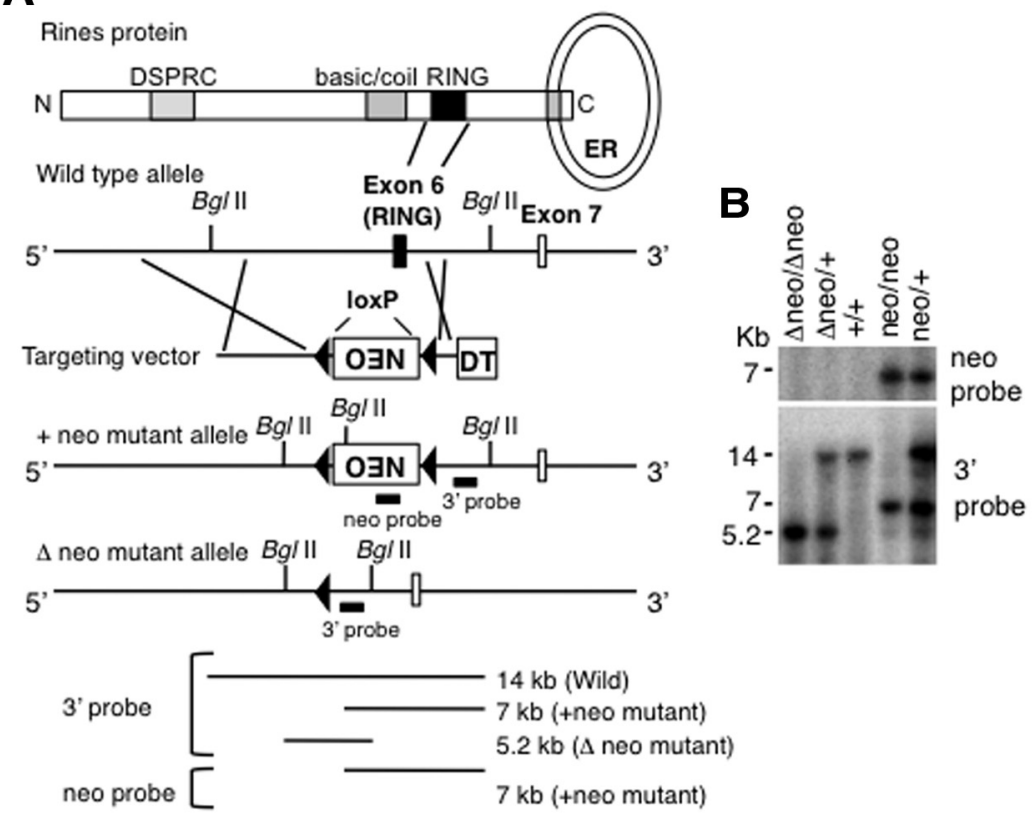

C

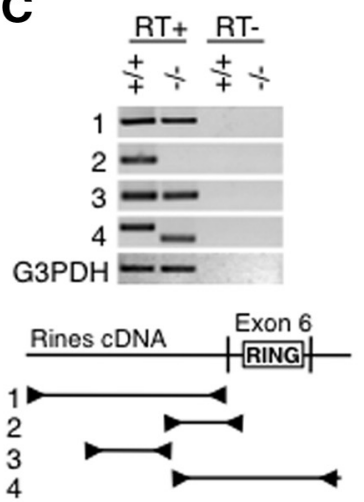

\begin{tabular}{|l|c|c|c|}
\hline & Rines +/+ & Rines +/- & Rines -/- \\
\hline$\%$ & 25.3 & 50.4 & 24.3 \\
\hline
\end{tabular}

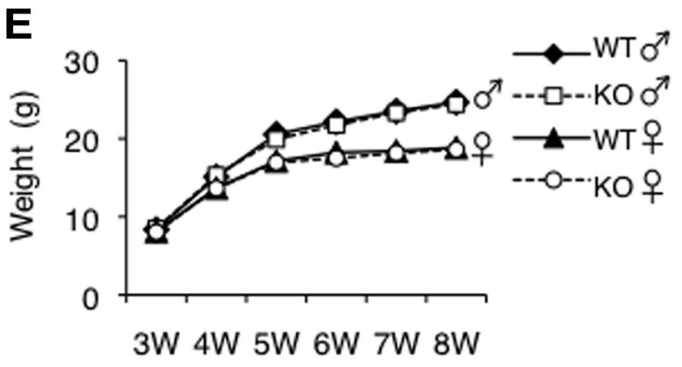

$\mathbf{F}$

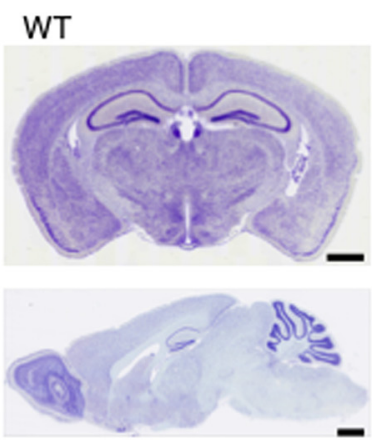

KO
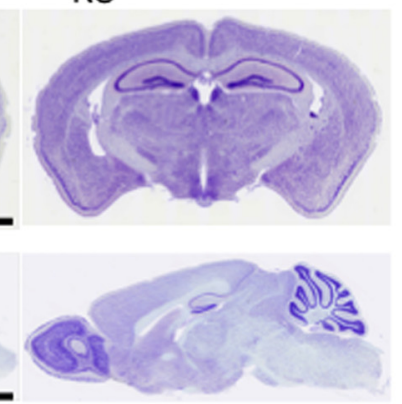

G

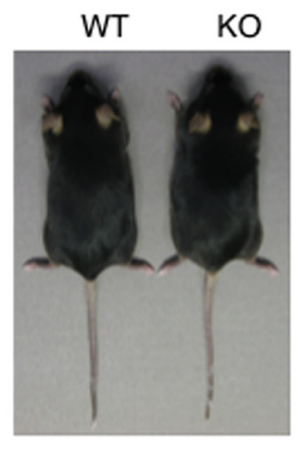

Figure 2. Rines KO strategy and histology of Rines KO brain. $A$, Structures of the Rines protein, gene, targeting vector, and mutated allele. The sixth exon, which contains the RING finger domain (black box), was replaced with the neomycin resistance gene cassette (NEO), excised by Cre recombinase in germline cells and flanked by loxP sequences. The location of the $3^{\prime}$ and neoprobes used for Southern blotting and the expected size of the hybridizing fragments with $3^{\prime}$ and neoprobes after Bglll digestion are shown. $\boldsymbol{B}, \boldsymbol{C}$, Confirmation of the mutant alleles by Southern blotting $(\boldsymbol{B})$ and RT-PCR analysis ( $(\boldsymbol{)}$. The locations of the 1-4 primers used for the RT-PCR analysis are shown. $\boldsymbol{D}-\boldsymbol{F}$, Survival rates, body growth, and brain histology of Rines KO mice. $\boldsymbol{D}$, Genotype percentages in the 21623 -week-old progenies from interheterozygote mating. There were no significant differences in the percentages of each genotype when we analyzed the data by a $\chi^{2}$ test $(p=0.74) . E$, Body weight curves of male and female WT and Rines K0 mice from weaning period ( 3 weeks) to 8 weeks. Male: WT, $n=19 ; \mathrm{K} 0, n=21$, Female: WT, $n=18 ; \mathrm{K} 0, n=$ 21. F, Cresyl violet staining of brain sections of 2-month-old WT and Rines KO mice. Scale bar, $1 \mathrm{~mm}$. G, Dorsal views of WT and Rines $\mathrm{K} 0$ mice at 7.5 months.

ms, lead time $100 \mathrm{~ms}$ ) and $120 \mathrm{~dB}$ pulse; $75 \mathrm{~dB}$ prepulse $(20 \mathrm{~ms}$, lead time $100 \mathrm{~ms})$ and $120 \mathrm{~dB}$ pulse; and $80 \mathrm{~dB}$ prepulse $(20 \mathrm{~ms}$, lead time 100 $\mathrm{ms}$ ) and $120 \mathrm{~dB}$ pulse. Each trial type was repeated 10 times in quasirandom order at random intertrial intervals $(10-20 \mathrm{~s})$. In the final session, 10 startle stimuli ( $120 \mathrm{~dB}, 40 \mathrm{~ms})$ were again presented at random intertrial intervals $(10-20 \mathrm{~s})$. Commercially available apparatuses and data analysis software were used (Mouse Startle software; O’Hara).

Morris water maze test. A circular maze made of white plastic $(1 \mathrm{~m}$ in diameter, $30 \mathrm{~cm}$ in depth) was filled with water to a depth of $\sim 20$ $\mathrm{cm}\left(22-23^{\circ} \mathrm{C}\right)$. The water was colored with white paint so that the mice could not see the platform $(20 \mathrm{~cm}$ high, $10 \mathrm{~cm}$ in diameter; $1 \mathrm{~cm}$ below the surface of water) or other cues under the water. Various extramaze landmark cues (i,e., a calendar, figure, and plastic box) were visible to the mice in the maze. Movements in the maze were recorded and analyzed with ImageJ WM software (O'Hara). Each mouse received six trials (one session) daily for four consecutive days. Each acquisition trial began when an individual mouse was placed into the water facing the outer edge of the maze at one of four designated starting points quasirandomly. The submerged platform remained constant for each mouse throughout testing. A trial ended when the mouse reached the platform, and the latency and distance swum were measured. Mice that did not reach the platform within the cutoff time of $60 \mathrm{~s}$ were removed from the water and placed on the platform for $30 \mathrm{~s}$ before being toweled off and placed back into their home cage. The intertrial interval was $\sim 6 \mathrm{~min}$. In the probe test conducted after the $4 \mathrm{~d}$ of training, the platform was taken away and each mouse was placed into the water at the position opposite to the target platform and allowed to swim for $60 \mathrm{~s}$. The distance swum, number of crossings, positions of the target and three nontarget platforms, and times spent in the quadrants of the four platforms were measured.

Rotarod test. The time that a mouse placed on a rotating rod (O'Hara) could maintain its balance walking on the rod was measured. The speed of rotation, which was $4 \mathrm{rpm}$ on day 1 , was increased from 4 to $40 \mathrm{rpm}$ over a $4 \mathrm{~min}$ period and then maintained at $40 \mathrm{rpm}$ for 1 min on days $2-5$. The mice were tested during a single 2 min trial on day 1 and during 4 trials, each with a maximum time of $300 \mathrm{~s}$ (intertrial interval, 20-30 s) on days 2-5. The time between placement and falling off or revolving around the rod was manually recorded.

Drug administration tests. The average volume of water consumed per day was measured before the administration of the nonselective and irreversible MAO inhibitor tranylcypromine (TCP; Sigma). TCP ( $\sim 3 \mathrm{mg} / \mathrm{kg})$ dissolved in drinking water was provided ad libitum chronically for 11-23 d. Subsequently, the open field, light-dark box, and forced swimming tests were performed as described above except that the mice were kept in groups of $3-5$ before the tests. Tests were performed with male mice, 6-7 months old (open 
field) or 6-17 months old (light-dark box and forced swimming tests). The immobility time in the forced swimming test was analyzed using the Supermex apparatus and CompACT FSS software (Muromachi-kikai). The TCP dose was chosen to fully inhibit MAO-A (Maki et al., 2000; Weber et al., 2009). Clorgyline (Sigma) was dissolved in sterile saline. The mice were kept in isolation for at least 1 week before the behavioral experiments and testing was conducted on 6- to 7-month-old male mice. On the conditioning day of the passive avoidance test, the mice were injected intraperitoneally with 5 $\mathrm{ml} / \mathrm{kg}$ sterile saline or clorgyline $(0.1-1 \mathrm{mg} / \mathrm{kg}) 2.5 \mathrm{~h}$ before the electric foot shock. This interval was chosen because $2-4.5 \mathrm{~h}$ after clorgyline pretreatment $(0.1-10 \mathrm{mg} / \mathrm{kg})$ in mice, apparent monoamine turnover in the brain attenuated without changes in horizontal locomotor activities (Kitanaka et al., 2006).

Neurochemical analysis. Quiet (control) male mice, 7-8 months old, were left undisturbed in their home cages. Mice of comparable age in the foot shock group were delivered 20 shocks $(0.2 \mathrm{~mA}, 1 \mathrm{~s})$ randomly during a 20 min period in a plastic chamber equipped with a stainless steel grid floor wired to a shock generator. This stressful treatment alters monoamine turnover and behavioral responses (Swiergiel et al., 2008). The mice were decapitated immediately after the foot shock period. The brains were collected, and $150-\mu \mathrm{m}$-thick frozen coronal sections were prepared. Circular tissue punches were collected from the medial prefrontal cortex, basolateral and cortical nuclei of the amygdala, substantia nigra, raphe nuclei, and LC using disposable biopsy needles (Biopsy Punch; Kai Medical) with diameters of 1, 2, 1.5, 1.5, and $2 \mathrm{~mm}$, respectively. The samples were homogenized in $0.1 \mathrm{~m}$ perchloric acid containing $0.1 \mathrm{~mm}$ EDTA and centrifuged for $15 \mathrm{~min}$ at $20,000 \times g$ at $4^{\circ} \mathrm{C}$. The supernatant was then filtered through $0.22 \mu \mathrm{m}$ polyvinylidene fluoride (PVDF) micropore filters (Millipore), and the filtrate was analyzed by high-pressure liquid chromatography (HPLC) coupled to an electrochemical detection system (graphite electrode vs Ag/AgCL reference, Eicom). Briefly, a Prepak AC-ODS $4.0 \times 5.0 \mathrm{~mm}$ precolumn and an Eicompak SC-5ODS $3.0 \times 150 \mathrm{~mm}$ column were used for separations; the perfusate was a mobile phase consisting of $44.7 \mathrm{~mm}$ citrate, $40.3 \mathrm{~mm}$ sodium acetate, $15 \%$ methanol, $190 \mathrm{mg} / \mathrm{L}$ sodium 1-octanesulfonate, and $5 \mathrm{mg} / \mathrm{L}$ EDTA, adjusted to $\mathrm{pH} 3.7$ using glacial acetic acid and pumped at a rate of $0.5 \mathrm{ml} / \mathrm{min}$. The working electrode (WE-3G) potential was set at $+0.5 \mathrm{~V}$. The column temperature was maintained at $25^{\circ} \mathrm{C}$. The HPLC data were collected automatically and analyzed by EZChrom Elite (Scientific Software). Protein was measured using a DC Protein Assay kit (Bio-Rad). All analyte information, including the retention times, peak heights, concentrations, and recovery rate of the internal standards, were calculated in relation to standard curves generated for known concentrations of external standards run daily.

Measurement of MAO-A activity. Circular tissue punches of the medial prefrontal cortex, basolateral nucleus of the amygdala, substantia nigra, raphe nuclei, and LC were collected using disposable biopsy needles (Biopsy Punch; Kai Medical) with diameters of $1,1,1.5,1.5$, and $1.5 \mathrm{~mm}$, respectively, from $150-\mu \mathrm{m}$-thick frozen coronal brain sections of 7- to 9-monthold male mice. MAO-A activity was measured with an MAO-Glo Assay kit (Promega). Tissues were homogenized in ice-cold $100 \mathrm{~mm}$ HEPES-KOH, $\mathrm{pH} 7.4,5 \%$ glycerol, and a complete protease inhibitor mixture (Roche) solution. An aliquot of the homogenate corresponding to $2 \mu \mathrm{g}$ of protein was used for each MAO-A reaction. The luminescent signal was measured with a Mini Lumat LB9506 luminometer (Berthold Technology).

Immunofluorescence staining. Immunofluoresence staining was performed as described previously (Inoue et al., 2004). Male mice 7-8 months old were fixed in $4 \%$ paraformaldehyde. Cryosections of their brains (20 $\mu \mathrm{m}$ in thickness) were prepared and reacted with primary antibodies after blocking with $2 \%$ normal donkey serum (Jackson ImmunoResearch) and $0.1 \%$ Triton X-100 in PBS. Immunopositive signals were detected with Alexa Fluor 488- or Alexa Fluor 594-labeled secondary antibodies (Invitrogen). Fluorescence-labeled preparations were imaged under a Fluoview FV1000 confocal microscope (Olympus). Signal intensities were measured with MetaMorph software (Molecular Devices). The relative area of DAPI staining and the number of stained cells in the LC regions were measured with ImageJ software. The LC regions were defined by $\mathrm{TH}$-immunostaining clusters. For morphometrical
Table 1. Behavioral tests

\begin{tabular}{|c|c|c|}
\hline & WT & K0 \\
\hline Body weight (g) & $30.2 \pm 0.39$ & $30.4 \pm 0.50$ \\
\hline \multicolumn{3}{|l|}{ Home cage activity } \\
\hline Whole day (per 30 min on days $1-7$ ) (AU) & $231.31 \pm 15.19$ & $224.43 \pm 16.32$ \\
\hline \multicolumn{3}{|l|}{ Open field test } \\
\hline Total distance $(\mathrm{cm})$ & $5625.78 \pm 258.56$ & $6084.73 \pm 377.61$ \\
\hline Total number of moving events & $257.5 \pm 5.08$ & $231.0 \pm 6.04^{* *}$ \\
\hline Total center time (s) & $214.41 \pm 14.42$ & $139.58 \pm 8.83^{* * *}$ \\
\hline \multicolumn{3}{|l|}{ Elevated plus maze test } \\
\hline Total distance $(\mathrm{cm})$ & $607.54 \pm 38.66$ & $609.79 \pm 52.59$ \\
\hline Spent time in open arms (\%) & $12.65 \pm 3.04$ & $1.78 \pm 0.50^{*}$ \\
\hline Entries into open arms (\%) & $24.59 \pm 4.32$ & $13.77 \pm 3.32$ \\
\hline \multicolumn{3}{|l|}{ Light-dark box transition test } \\
\hline Total distance $(\mathrm{cm})$ & $1079.91 \pm 117.79$ & $969.80 \pm 119.51$ \\
\hline Latency to enter dark box (s) & $33.68 \pm 8.36$ & $28.44 \pm 9.78$ \\
\hline Light/dark transitions & $26.16 \pm 1.72$ & $25.69 \pm 2.00$ \\
\hline Distance traveled in light box & $35.09 \pm 1.47$ & $37.91 \pm 1.69$ \\
\hline Time in light box (\%) & $34.80 \pm 2.09$ & $36.53 \pm 2.59$ \\
\hline \multicolumn{3}{|l|}{ Passive avoidance test } \\
\hline Latency in conditioning (s) & $10.5 \pm 2.05$ & $11.1 \pm 4.13$ \\
\hline Latency in $24 \mathrm{~h}$ test (s) & $553.5 \pm 106.18$ & $71.7 \pm 31.47^{* *}$ \\
\hline \multicolumn{3}{|l|}{ Forced swimming test } \\
\hline Immobility time on day $1(\%)$ & $38.16 \pm 2.63$ & $38.42 \pm 2.90$ \\
\hline Immobility time on day $2(\%)$ & $51.87 \pm 3.74$ & $33.56 \pm 3.70^{* *}$ \\
\hline \multicolumn{3}{|l|}{ Morris water maze test } \\
\hline \multicolumn{3}{|l|}{ Escape latency in training (s) } \\
\hline Day 1 & $45.54 \pm 3.42$ & $44.94 \pm 3.64$ \\
\hline Day 4 & $20.50 \pm 3.96$ & $18.91 \pm 2.52$ \\
\hline \multicolumn{3}{|l|}{ Probe test } \\
\hline Time in target (\%) & $35.92 \pm 5.18$ & $36.58 \pm 3.71$ \\
\hline Number of target crossings (\%) & $42.95 \pm 11.61$ & $38.84 \pm 5.21$ \\
\hline Tail flick test (latency) (s) & $2.29 \pm 0.09$ & $2.42 \pm 0.09$ \\
\hline \multicolumn{3}{|l|}{ Hot plate test } \\
\hline Licking of forepaws (latency) & $18.56 \pm 0.74$ & $19.54 \pm 1.44$ \\
\hline Flinch of hindpaws (latency) (s) & $26.46 \pm 1.43$ & $27.20 \pm 1.76$ \\
\hline \multicolumn{3}{|l|}{ Rotarod test (latency to fall) (s) } \\
\hline Day 1 & $124.70 \pm 11.07$ & $108.95 \pm 11.36$ \\
\hline Day 4 & $163.53 \pm 10.33$ & $162.10 \pm 14.07$ \\
\hline \multicolumn{3}{|l|}{ Auditory startle response (AU) } \\
\hline Intensity: $70 \mathrm{~dB}$ & $0.10 \pm 0.01$ & $0.11 \pm 0.01$ \\
\hline Intensity: $120 \mathrm{~dB}$ & $3.35 \pm 0.49$ & $2.63 \pm 0.29$ \\
\hline \multicolumn{3}{|l|}{$\begin{array}{l}\text { Prepulse inhibition test (startle stimulus: } 120 \\
\text { dB) (\%inhibition) }\end{array}$} \\
\hline Intensity: $70 \mathrm{~dB}$ & $14.88 \pm 3.97$ & $2.74 \pm 6.38$ \\
\hline Intensity: $80 \mathrm{~dB}$ & $33.78 \pm 5.23$ & $37.53 \pm 12.72$ \\
\hline \multicolumn{3}{|l|}{ Social interaction test } \\
\hline $5 \mathrm{~h}$ & $1.39 \pm 0.094$ & $1.16 \pm 0.038^{*}$ \\
\hline $6 \mathrm{~h}$ & $1.43 \pm 0.073$ & $1.24 \pm 0.042^{*}$ \\
\hline \multicolumn{3}{|l|}{ Resident-intruder test } \\
\hline Social investigation duration (s) & $55.34 \pm 6.39$ & $84.78 \pm 10.04^{*}$ \\
\hline Latency to first attack (s) & $450.96 \pm 65.26$ & $506.46 \pm 62.37$ \\
\hline Fighting duration (s) & $3.41 \pm 2.15$ & $0.96 \pm 0.77$ \\
\hline Number of fighting bouts & $1.3 \pm 0.6$ & $0.7 \pm 0.6$ \\
\hline Hidden cookie test (latency to find food) (s) & $150.04 \pm 15.80$ & $159.24 \pm 12.21$ \\
\hline
\end{tabular}

Data represent the mean \pm SEM. ${ }^{*} p<0.05,{ }^{* *} p<0.01,{ }^{* * *} p<0.001$, Student's $t$ test (open field, passive avoidance, social interaction, and resident-intruder tests) or Mann-Whitney $U$ test (elevated plus maze and forced swimming tests) compared with WT mice. For home cage activity, passive avoidance test, Morris water maze test, rotarod test, auditory response test, prepulse inhibition test, social interaction test, resident-intrudertest, and hidden cookietest:WT, $n=10$; KO $n=10$. For body weight:WT, $n=59 ; \mathrm{KO}, n=50$. For open field test:WT, $n=16 ; \mathrm{KO}, n=12$. For elevated plus maze test: $\mathrm{WT}, n=37 ; \mathrm{K} 0, n=30$. For light-dark box transition test:WT, $n=38 ; \mathrm{KO}, n=32$. Forforced swimming test and tail flick test: $\mathrm{WT}, n=22 ; \mathrm{KO}, n=20$. For hot plate test: $\mathrm{WT}, n=21 ; \mathrm{KO}, n=20$. AU, arbitrary unit.

analyses, cryosections of brains were stained with cresyl violet, thionine, or toluidine blue.

cDNA cloning and plasmid construction. Full-length mouse MAO-A cDNA was obtained from a FANTOM3 clone set (Carninci et al., 2005). Flag- and HA-tagged MAO-A expression vectors were constructed by inserting the epitope tags and the protein coding region in-frame into the 
A
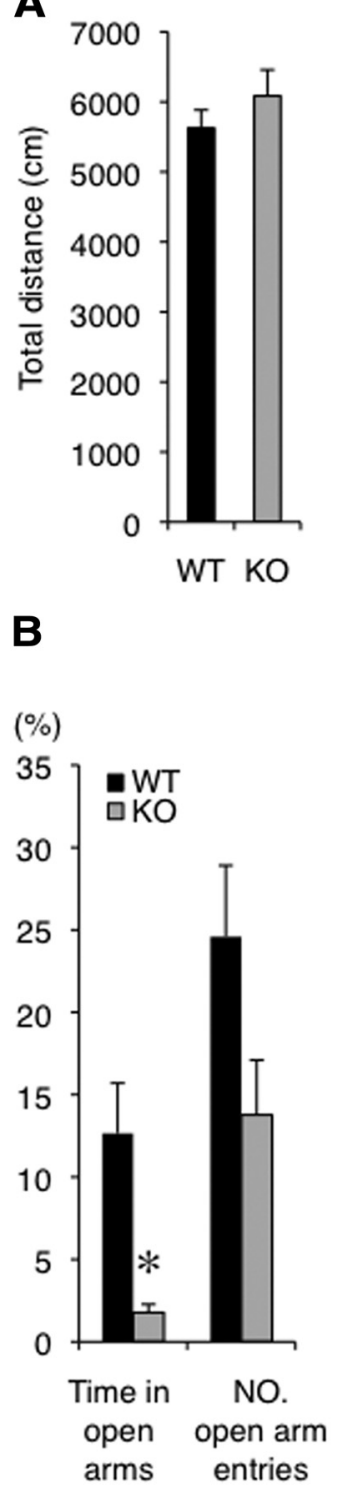
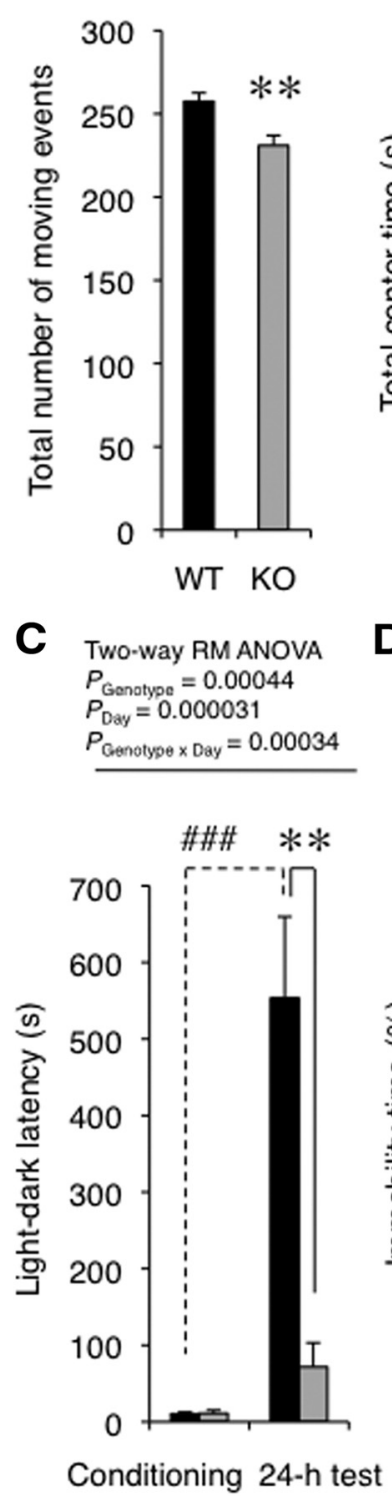

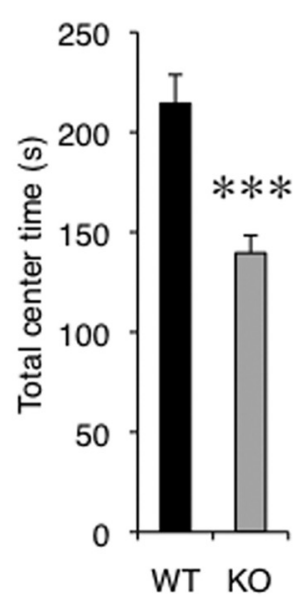

D
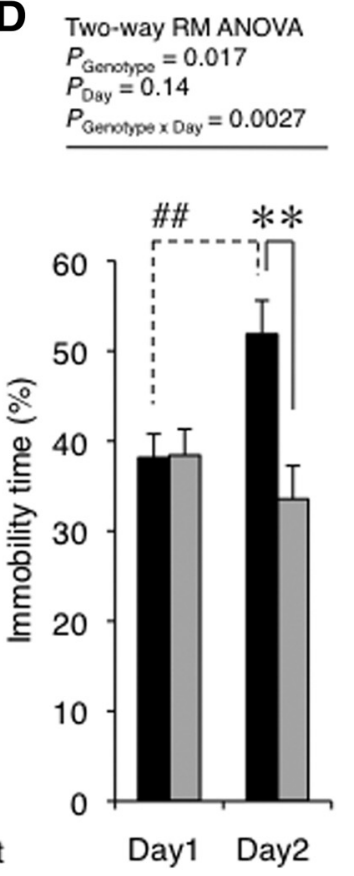

Figure 3. Rines $\mathrm{KO}$ mice showed changes in emotional behaviors. $A$, Open field test. Horizontal locomotor activities of WT and Rines $\mathrm{KO}$ mice in the open field arena $(50 \times 50 \mathrm{~cm})$ were assessed for $15 \mathrm{~min}$. The traveled distance of $\mathrm{KO}$ mice was not significantly different from that of WT mice (left). The number of total moving events and the time spent in the center zone (36\%) of the open field arena significantly decreased in $\mathrm{KO}$ mice (middle, right). In a moving event, a mouse continued moving for $2 \mathrm{~s}$ or more. WT, $n=16 ; \mathrm{K} 0, n=12 ;{ }^{* *} p<0.01,{ }^{* *} p<0.001$ by Student's $t$ test. $\boldsymbol{B}$, Elevated plus maze test. Both time spent in open arms and numbers of entries into open arms decreased in Rines KO. WT, $n=37 ; \mathrm{KO}, n=30 ;{ }^{*} p<0.05$ by Mann-Whitney U test. $\boldsymbol{C}$, Passive avoidance test. After habituation to a light-dark box, mice were conditioned with an electric foot shock upon entering the dark compartment (conditioning). Twenty-four hours after conditioning, the mice were reintroduced into the box and the latency to enter the dark compartment (light-dark latency) was measured (24 h test). The light-dark latency of K0 mice significantly decreased relative to that of WT mice in the $24 \mathrm{~h}$ test. WT, $n=10 ; \mathrm{KO}, n=10 ;{ }^{* *} p<0.01$, Welch's $t$ test (solid lines); ${ }^{\# \# \#} p<$ 0.001 , paired $t$ test (dotted lines). D, Forced swimming test. Mice were confined to an inescapable test chamber filled with water on two successive days and immobility time (i.e., time spent without swimming) was measured for 15 min (Day1) and 5 min (Day2). The immobility time of K0 mice was significantly less than that of WT mice on day 2 . WT, $n=22 ; \mathrm{K} 0, n=20$; ${ }^{* *} p<0.01$, Mann-Whitney $U$ test; ${ }^{\# \#} p<0.01$, Wilcoxon signed-rank test (dotted lines).

pcDNA3.1 vector (Invitrogen). Other expression vectors were constructed as described previously (Ogawa et al., 2008).

Immunoblotting. The proteins and gene products were separated by 7.5\%-10\% SDS-PAGE and transferred to PVDF membranes (Immobilon; Millipore). The membranes were immersed in 5\% skim milk overnight at $4^{\circ} \mathrm{C}$ and incubated with the first antibody. The bound antibodies were detected using horseradish peroxidase-conjugated secondary antibodies (anti-mouse, rabbit IgG) and ECL or ECL Plus reagents (GE Healthcare).

Immunoprecipitation, ubiquitination, and degradation assays. In the immunoprecipitation assay, HEK293T cells transfected with vectors were treated with the proteasome inhibitor epoxomicin ( $5 \mu \mathrm{m}$; Peptide Institute) for $9 \mathrm{~h}$ and lysed in an immunoprecipitation buffer (20 mм HEPES, pH 7.4, 150 mm NaCl, 5 mm EDTA, 10\% glycerol, $0.5 \%$ Triton X-100, 0.5 $\mathrm{mm} N$-ethylmaleimide, $0.5 \mathrm{~mm}$ iodoacetamide) and a complete protease inhibitor mixture (Roche). The lysates were subjected to immunoprecipitation as described previously (Ogawa et al., 2008). In the ubiquitination assay with cultured cells, NIH3T3 cells were lysed in an immunoprecipitation buffer with $20 \mathrm{~mm}$ $N$-ethylmaleimide, $5 \mathrm{~nm}$ ubiquitin aldehyde (Calbiochem), $20 \mathrm{~mm}$ sodium fluoride, $2 \mathrm{~mm}$ sodium orthovanadate, and $50 \mu \mathrm{M}$ MG132 (Peptide Institute). The lysates were subjected to immunoprecipitation as described previously (Ogawa et al., 2008; Kawabe et al., 2010). In the degradation assay, NIH3T3 cells were lysed in SDS lysis buffer (50 mM Tris- $\mathrm{HCl}, \mathrm{pH}$ 7.5, 0.5 mм EDTA, 1\% SDS, 1 mm dithiothreitol), boiled for $10 \mathrm{~min}$, diluted 5 -fold by adding $0.5 \%$ NP-40 with a complete protease inhibitor mixture (Roche), and subjected to immunoblotting as described previously (Ogawa et al., 2008). In the ubiquitination assay for LC, circular tissue punches of the LC ( $2 \mathrm{~mm}$ in diameter) were collected from $150-\mu \mathrm{m}$-thick frozen coronal brain sections of 8.5-month-old WT or Rines KO male mice. LC tissue punches were lysed in an immunoprecipitation buffer and sonicated for $20 \mathrm{~s}$. The lysates were subjected to immunoprecipitation using anti-MAO-A antibody (MAO-A IP-WB antibody pair), after which time the ubiquitinated MAO-A was detected with an anti-ubiquitin-protein conjugate antibody.

Statistics. Statistical analyses were conducted using the Prism 4 statistical package (GraphPad). Parametric data were analyzed using Student's $t$ test, Welch's $t$ test, or the paired $t$ test; nonparametric data were analyzed using Mann-Whitney $U$ test or Wilcoxon's signed-rank test. The effects of factors were analyzed using two-way ANOVA or two-way repeated-measures ANOVA. Data are presented as mean \pm SEM. Differences were defined as statistically significant when $p<0.05$.

\section{Results}

Rines possesses RING finger-dependent E3 ubiquitin ligase activity and shows high expression levels in the postnatal brain (Fig. 1; Ogawa et al., 2008). Here, Rines mRNA in the brain was consistently detected in 1- to 10-month-old mice (Fig. $1 A)$ and Rines mRNA and protein were observed in each brain region (Fig. $1 B, C$ ). However, the authentic target molecule and physiological function of Rines remained unknown. To determine the physiological role of Rines, we generated Rines KO mice that lack exon 6, which includes the RING finger domain (Fig. 2A-C). We found that Rines KO mice had normal survival rates (Fig. $2 D$ ), body growth (Fig. $2 E$ ), gross brain mor- 
phology (Fig. 2F), and external appearance (Fig. 2G). To explore the role of Rines in higher cognition, we performed a series of behavioral tests (Table 1).

Rines KO mice exhibited emotional behavior abnormalities (Fig. 3). The total number of moving events and time spent in the center of an open field decreased in KO compared with WT mice (Fig. 3A: total number of moving events, Student's $t$ test, $t=3.37$, $p=0.0023$; total center time, Student's $t$ test, $t=4.43, p=$ 0.00018 ). These results suggest that Rines KO mice were reluctant to explore a novel environment. In addition, the time spent in the open arm of the elevated plus maze test decreased (Fig. 3B: Mann-Whitney $U$ test, $U=362.50, p=0.015)$. However, the total distances in the open field test and home cage activity were unaltered (Fig. 3A: total distance, Student's $t$ test, $t=1.05, p=0.31$; Table 1: home cage activity, whole day, two-way repeatedmeasures ANOVA, $F_{\text {genotype }(1,108)}=0.095, p=0.76 ; F_{\text {day }(6,108)}=$ $1.96, p=0.078 ; F_{\text {genotype }} \times$ day $(6,108)=1.65, p=0.14$; dark phase, two-way repeated-measures ANOVA, $F_{\text {genotype }(1,126)}=0.054$, $p=0.82 ; F_{\text {day }(7,126)}=1.48, p=0.18 ; F_{\text {genotype } \times \text { day }(7,126)}=1.49$, $p=0.18$; light phase, two-way repeated-measures ANOVA, $F_{\text {genotype }(1,108)}<0.0001, p=0.999 ; F_{\text {day }(6,108)}=1.49, p=0.19$; $\left.F_{\text {genotype } \times \text { day }(6,108)}=0.38, p=0.89\right)$. In addition, the latencies to fall in the rotarod test were also comparable to those of WT mice (Table 1: two-way repeated-measures ANOVA, $F_{\text {genotype }(1,54)}=$ $0.016, p=0.90 ; F_{\mathrm{day}}(3,54)=14.62, p<0.0001 ; F_{\text {genotype }} \times$ day $(3,54)=$ $1.71, p=0.18)$. These results indicate that Rines $\mathrm{KO}$ mice show normal locomotor and motor coordination abilities. Together with these results, the abnormalities observed in the open field and the elevated plus maze tests indicate that anxiety-like behavior in a novel environment was enhanced in Rines KO mice. Abnormal responses to stressful events were also observed in the passive avoidance and forced swimming tests (Fig. 3C,D). In the former, the latency of KO mice to enter the dark area after conditioning was significantly reduced compared with WT mice (Fig. 3C: conditioning, WT vs KO, Welch's $t$ test, $t=0.13, p=0.90 ; 24$ h test, WT vs KO, Welch's $t$ test, $t=4.35, p=0.0014$; WT, conditioning vs $24 \mathrm{~h}$ test, paired $t$ test, $t=5.15, p=0.00061$; KO, conditioning vs $24 \mathrm{~h}$ test, paired $t$ test, $t=2.06, p=0.070$; two-way repeated-measures ANOVA, $F_{\text {genotype }(1,18)}=18.42, p=0.00044 ; F_{\text {day }(1,18)}=30.37$, $p=0.000031 ; F_{\text {genotype }} \times$ day $\left.(1,18)=19.40, p=0.00034\right)$. In addition, forced swimming tests performed on two successive days to observe stress reactivity revealed that the percentage of time spent immobile by WT mice on the second day was significantly higher than that on the first day (Fig. 3D: WT, Wilcoxon signed-rank test, $W=177, p=0.0043)$. These results indicate a despaired response to the stress suffered from the long period of forced swimming on the first day (Duncan et al., 1993). However, KO mice did not show such a response (Fig. $3 D$ : KO, Wilcoxon signed-rank test, $W=64, p=0.24$ ) and their time spent immobile was significantly less than that of WT mice on the second day (Fig. 3D: Day1, Mann-Whitney $U$ test, $\mathrm{U}=208, p=0.77$; Day2, Mann-Whitney $U$ test, $U=102, p=0.0031$, two-way repeatedmeasures ANOVA, $F_{\text {genotype }(1,40)}=6.23, p=0.017 ; F_{\text {day }(1,40)}=$ $2.31, p=0.14 ; F_{\text {genotype }} \times$ day $\left.(1,40)=10.20, p=0.0027\right)$.

To determine whether nociception was altered in Rines KO mice, we performed the tail flick and hot plate tests. Latencies to remove the tail from the heat and responses to the hot plate were unchanged in Rines KO mice (Table 1: tail flick, Student's $t$ test, $t=1.02, p=0.31$; hot plate, licking of forepaws, Welch's $t$ test, $t=0.60, p=0.55$; flinch of hindpaws, Student's $t$ test, $t=0.33$, $p=0.74)$. In addition, in the Morris water maze test, there were no differences between WT and KO mice in the escape latency
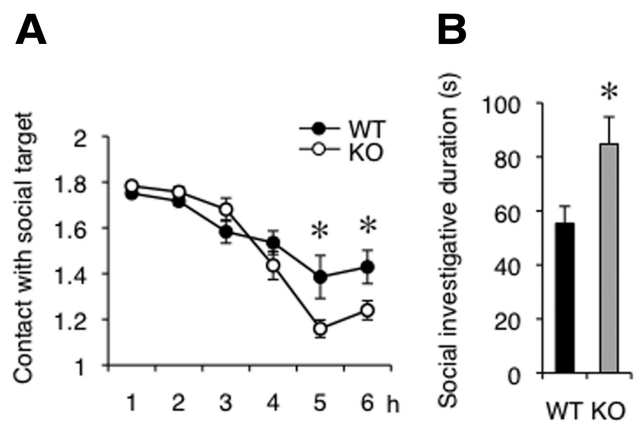

Figure 4. Increased affiliative behaviors in Rines $\mathrm{KO}$ mice. $A$, Contact between Rines $\mathrm{K} O$ and unfamiliar C57BL/6J mice in a novel environment. In the computer analysis, each mouse was represented by a particle. Particle numbers 2 and 1 indicate the statuses of separated and contacted, respectively. The mean particle numbers, as contacts with a social target, were calculated for each time bin ( $1 \mathrm{~h})$. Rines $\mathrm{K} 0$ mice showed a significant increase in the duration of contact with unfamiliar mice compared with WT mice. WT, $n=10 ; \mathrm{KO}, n=10$; ${ }^{*} p<0.05$, Student's $t$ test or Welch's $t$ test. $\boldsymbol{B}$, Resident-intruder test. The bar graph shows the time spent in investigation (e.g., sniffing and following) of WT or KO mice (resident) to intruder mice (BALB/c male mice). Rines K0 mice showed a significant increase in the duration of social investigation compared with WT mice. WT, $n=10 ; \mathrm{K} 0, n=10 ;{ }^{*} p<0.05$, Student's $t$ test.

during training or the time in the target quadrant during the probe trials (Table 1: escape latency, two-way repeated-measures ANOVA, $F_{\text {genotype }(1,54)}=0.24, p=0.63 ; F_{\text {day }(3,54)}=42.8, p<$ $0.0001 ; F_{\text {genotype }} \times$ day $(3,54)=0.12, p=0.95$; probe test, time in target, Mann-Whitney $U$ test, $U=49.5, p=0.97$; number of times crossing target, Mann-Whitney $U$ test, $U=50, p=1$ ). These results indicate that Rines $\mathrm{KO}$ mice are not deficient in nociception or various cognitive functions. Accordingly, the abnormal responses of Rines $\mathrm{KO}$ mice in the passive avoidance and forced swimming tests suggest that emotional responses, which might be interpreted in terms of reduced attention, aversive memory formation, or stress reactivity, are altered in Rines KO mice.

Altered emotional responses were also observed upon the receipt of social inputs (Fig. 4A,B). Rines KO mice showed significant increases in the duration of contact with conspecifics in unfamiliar space during a social interaction test (Fig. $4 A: 5 \mathrm{~h}$, Welch's $t$ test, $t=2.23, p=0.047 ; 6$ h, Student's $t$ test, $t=2.19$, $p=0.043)$. When they encountered unfamiliar $\mathrm{BALB} / \mathrm{c}$ intruder mice in a resident-intruder test, the time spent in social investigation (e.g., sniffing or following the intruder) significantly increased in Rines KO mice (Fig. 4B: Student's $t$ test, $t=2.48, p=$ $0.024)$. Considering that there were no significant alterations in the hidden cookie, auditory startle response, or prepulse inhibition tests (Table 1: latency to find food in hidden cookie test, Student's $t$ test, $t=0.33, p=0.75$; auditory startle response, two-way repeated-measures ANOVA, $F_{\text {genotype }(1,144)}=0.60, p=$ $0.45 ; F_{\mathrm{dB}(8,144)}=91.27, p<0.0001 ; F_{\text {genotype }} \times \mathrm{dB}(8,144)=1.33$, $p=0.23$, prepulse inhibition, two-way repeated-measures ANOVA, $F_{\text {genotype }(1,36)}=0.036, p=0.85 ; F_{\mathrm{dB}(2,36)}=26, p<$ $\left.0.0001 ; F_{\text {genotype }} \times \mathrm{dB}(2,36)=2.82, p=0.073\right)$, the increased affiliative behaviors may not reflect altered olfactory or auditory functions.

Given the behavioral abnormalities, we investigated whether monoamine levels were altered in the LC, raphe nuclei, and substantia nigra of Rines $\mathrm{KO}$ mice because these brain areas are the principal sources of brain NE, 5-HT, and dopamine (Table 2). Because the behavioral abnormalities in Rines $\mathrm{KO}$ mice were observed during exposure to stressful stimuli, we also measured monoamine levels in mice in the presence of an aversive stimulus 
Table 2. Amounts of monoamines and their metabolites

\begin{tabular}{|c|c|c|c|c|c|c|c|}
\hline & & \multicolumn{2}{|c|}{$\mathrm{LC}$} & \multicolumn{2}{|c|}{ Prefrontal cortex } & \multicolumn{2}{|c|}{ Amygdala } \\
\hline & & Control & Foot shock & Control & Foot shock & Control & Foot shock \\
\hline \multirow[t]{2}{*}{$5-\mathrm{HT}$} & WT & $4667.6 \pm 58.4$ & $5223.4 \pm 188.8$ & $3873.8 \pm 471.7$ & $2698.7 \pm 214.9$ & $5698.8 \pm 161.6$ & $6596.1 \pm 120.5$ \\
\hline & $\mathrm{KO}$ & $4531.2 \pm 129.3$ & $4553.4 \pm 198.7 *$ & $2716.9 \pm 221.4^{*}$ & $3172.0 \pm 165.6$ & $6064.8 \pm 227.4$ & $6532.9 \pm 208.7$ \\
\hline \multirow[t]{2}{*}{$\mathrm{NE}$} & WT & $6948.6 \pm 276.1$ & $6723.0 \pm 155.7$ & $5460.0 \pm 422.4$ & $4209.5 \pm 233.0$ & $2932.9 \pm 54.9$ & $2453.5 \pm 72.9$ \\
\hline & $\mathrm{KO}$ & $6466.7 \pm 273.8$ & $5990.4 \pm 193.6^{*}$ & $5111.1 \pm 207.6$ & $4934.5 \pm 90.8^{*}$ & $3239.4 \pm 107.8^{*}$ & $2631.1 \pm 67.2$ \\
\hline \multirow{2}{*}{ DA } & WT & $499.6 \pm 28.2$ & $792.3 \pm 28.5$ & $1266.0 \pm 141.7$ & $1103.0 \pm 183.0$ & $5228.7 \pm 597.3$ & $8878.3 \pm 1260.1$ \\
\hline & $\mathrm{KO}$ & $518.3 \pm 25.3$ & $726.2 \pm 36.6$ & $1010.6 \pm 80.3$ & $1029.1 \pm 46.5$ & $6744.2 \pm 837.3$ & $7486.9 \pm 1157.6$ \\
\hline \multirow{2}{*}{ 5-HIAA } & WT & $5186.5 \pm 248.4$ & $6439.5 \pm 363.0$ & $2539.4 \pm 204.8$ & $2262.9 \pm 121.4$ & $3014.0 \pm 110.2$ & $4045.5 \pm 248.7$ \\
\hline & $\mathrm{KO}$ & $5149.1 \pm 531.2$ & $5161.3 \pm 287.5^{*}$ & $2161.6 \pm 234.9$ & $2392.3 \pm 103.7$ & $3323.2 \pm 188.4$ & $3807.7 \pm 188.5$ \\
\hline \multirow{2}{*}{ MHPG } & WT & $977.5 \pm 32.3$ & $1811.5 \pm 76.3$ & ND & ND & $363.5 \pm 20.1$ & $894.4 \pm 32.5$ \\
\hline & $\mathrm{KO}$ & $973.9 \pm 55.1$ & $1590.6 \pm 79.5$ & ND & $532.3 \pm 78.5$ & $421.3 \pm 21.5$ & $880.7 \pm 38.1$ \\
\hline \multirow{2}{*}{ DOPAC } & WT & $498.0 \pm 23.0$ & $1390.8 \pm 67.9$ & $654.6 \pm 50.7$ & $1350.6 \pm 96.3$ & $1292.4 \pm 112.5$ & $2861.4 \pm 251.5$ \\
\hline & $\mathrm{KO}$ & $534.1 \pm 41.7$ & $1247.7 \pm 53.7$ & $569.0 \pm 37.6$ & $1503.4 \pm 65.3$ & $1510.3 \pm 112.5$ & $2549.0 \pm 223.8$ \\
\hline \multirow[t]{2}{*}{ HVA } & WT & $691.2 \pm 32.7$ & $1238.3 \pm 65.2$ & $6948.6 \pm 276.1$ & $6723.0 \pm 155.7$ & \multicolumn{2}{|l|}{$1792.5 \pm 135.2$} \\
\hline & $\mathrm{KO}$ & $722.8 \pm 63.2$ & $1076.6 \pm 40.9$ & $1081.5 \pm 143.3$ & $2286.1 \pm 87.9$ & $2439.5 \pm 262.3$ & $3473.3 \pm 380.9$ \\
\hline
\end{tabular}

\begin{tabular}{|c|c|c|c|c|c|}
\hline & \multicolumn{2}{|c|}{ Raphe nucleus } & \multicolumn{2}{|c|}{ Substantia nigra } \\
\hline & & Control & Foot shock & Control & Foot shock \\
\hline \multirow{2}{*}{ 5-HT } & WT & $8599.4 \pm 651.0$ & $10420.1 \pm 516.1$ & $9365.1 \pm 461.1$ & $9068.4 \pm 478.3$ \\
\hline & $\mathrm{KO}$ & $10158.6 \pm 655.4$ & $10103.7 \pm 456.0$ & $9942.0 \pm 368.5$ & $9168.7 \pm 551.1$ \\
\hline \multirow{2}{*}{$\mathrm{NE}$} & WT & $8149.3 \pm 262.4$ & $6229.8 \pm 183.2$ & $3849.3 \pm 192.8$ & $4263.6 \pm 340.3$ \\
\hline & $\mathrm{KO}$ & $8118.8 \pm 327.1$ & $6756.8 \pm 222.9$ & $4629.3 \pm 349.0$ & $4514.2 \pm 309.8$ \\
\hline \multirow{2}{*}{ DA } & WT & $2749.8 \pm 1569.9$ & $1635.2 \pm 81.5$ & $5895.4 \pm 364.9$ & $5458.6 \pm 339.2$ \\
\hline & $\mathrm{KO}$ & $1470.9 \pm 60.7$ & $1703.4 \pm 65.1$ & $5785.5 \pm 407.5$ & $5049.2 \pm 453.4$ \\
\hline \multirow{2}{*}{ 5-HIAA } & WT & $8839.8 \pm 836.3$ & $12659.1 \pm 1424.6$ & $6149.4 \pm 386.8$ & $7155.7 \pm 281.0$ \\
\hline & KO & $11292.1 \pm 1235.3$ & $11222.7 \pm 714.6$ & $6904.7 \pm 501.1$ & $6831.4 \pm 418.0$ \\
\hline \multirow{2}{*}{ MHPG } & WT & $800.8 \pm 434.6$ & $1187.7 \pm 68.0$ & $460.6 \pm 33.1$ & $1026.8 \pm 63.6$ \\
\hline & KO & $454.1 \pm 23.5$ & $1191.3 \pm 91.1$ & $546.1 \pm 28.9$ & $1020.6 \pm 100.7$ \\
\hline \multirow{2}{*}{ DOPAC } & WT & $772.9 \pm 139.3$ & $1400.0 \pm 60.5$ & $2239.3 \pm 89.9$ & $2495.0 \pm 130.4$ \\
\hline & $\mathrm{KO}$ & $786.1 \pm 23.7$ & $1395.6 \pm 44.3$ & $2277.3 \pm 140.4$ & $2354.0 \pm 100.0$ \\
\hline \multirow{2}{*}{ HVA } & WT & $1591.2 \pm 213.1$ & $2291.5 \pm 158.2$ & $3119.6 \pm 124.8$ & $3585.8 \pm 159.1$ \\
\hline & KO & $1784.0 \pm 89.4$ & $2159.3 \pm 63.0$ & $3293.7 \pm 217.5$ & $3294.2 \pm 153.2$ \\
\hline
\end{tabular}

Values are presented as mean \pm SEM (pg/mg protein). $n=7-9$ mice per condition; ${ }^{*} p<0.05$, Student's t test compared with WT mice. There were significant genotype effects for 5 -HT and NE contents in LC and for NE contents in amygdala analyzed by two-way ANOVA ( $\left.{ }^{\#} p_{\text {genotype }}<0.05,{ }^{\# \#} p_{\text {genotype }}<0.01\right)$. There were significant effects of the interaction of genotype by treatment for 5-HT and NE contents in the prefrontal cortex and HVA contents in the amygdala analyzed

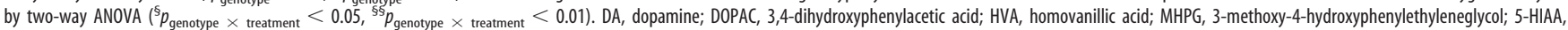
5-hydroxyindoleacetic acid; ND, not detected.

(electric foot shock). We observed significantly less NE and 5-HT levels in the LC of Rines KO mice than in the LC of WT mice after the aversive stimulus (Table 2: NE, Student's $t$ test, $t=2.89, p=$ 0.013 ; 5-HT, Student's $t$ test, $t=2.42, p=0.031$; NE, two-way ANOVA, $F_{\text {genotype }(1,27)}=6.52, p=0.017 ; F_{\text {treatment }(1,27)}=2.18$, $p=0.15 ; F_{\text {genotype } \times \text { treatment }(1,27)}=0.28, p=0.60 ; 5$-HT, two-way ANOVA, $F_{\text {genotype }(1,27)}=6.65, p=0.016 ; F_{\text {treatment }(1,27)}=3.42$, $\left.p=0.075 ; F_{\text {genotype } \times \text { treatment }(1,27)}=2.91, p=0.099\right) . \mathrm{NE}$ and
5-HT contents were also altered in the prefrontal cortex and amygdala, which receive projections from the LC and play important roles in emotional processing (Table 2). 5-HT levels in the prefrontal cortex of Rines KO mice were significantly less than those of WT mice under normal conditions (Table 2: Student's $t$ test, $t=2.39, p=0.031$; two-way ANOVA, $F_{\text {genotype }(1,27)}=1.48, p=$ $0.23 ; F_{\text {treatment }(1,27)}=1.64, p=0.21 ; F_{\text {genotype } \times \text { treatment }(1,27)}=$ $8.41, p=0.0073)$. Other than these regions, the raphe nuclei and 


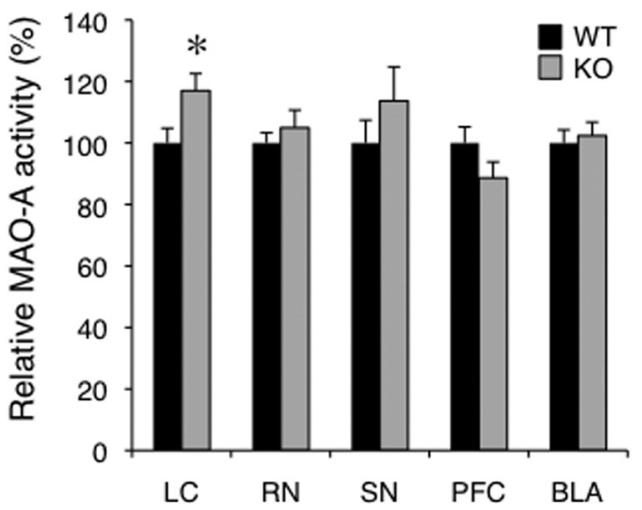

Figure 5. MAO-A enzymatic activities in Rines $\mathrm{KO}$ and WT mice. The enzymatic activities were measured in the LC, raphe nuclei (RN), substantia nigra (SN), prefrontal cortex (PFC), and basolateral nucleus of the amygdala (BLA) in WT and Rines $\mathrm{KO}$ mouse brains. Increased MAO-A activity was observed in the $\mathrm{LC}$ region of Rines $\mathrm{KO}$ mice. WT and $\mathrm{KO}, n=7-14$; ${ }^{*} p<0.05$, Student's $t$ test. WT values are indicated as $100 \%$.

substantia nigra showed comparable monoamine levels between WT and KO mice regardless of foot shock (Table 2). These results suggest that Rines KO mice have altered LC function and monoamine levels in certain brain regions.

MAO-A has an essential role in the metabolism of NE and 5-HT, and its expression is concentrated in the LC (Shih et al., 1999). MAO-A-deficient mice have increased levels of monoamines such as NE and 5-HT in the brain (Cases et al., 1995; Kim et al., 1997) and show behavioral phenotypes that are partially opposite to those of Rines KO mice (see Discussion). To clarify the effects of MAO-A in the Rines KO brain, we measured MAO-A activity in the LC and found that it was significantly higher than that in WT mice (Fig. 5: Student's $t$ test, $t=2.33, p=$ 0.028 ). There were no significant differences of MAO-A activity in other brain regions such as the raphe nuclei, substantia nigra, prefrontal cortex, or amygdala (Fig. 5: RN, Student's $t$ test, $t=$ $0.75, p=0.47$; SN, Student's $t$ test, $t=1.03, p=0.32$; PFC, Student's $t$ test, $t=1.48, p=0.16$; BLA, Student's $t$ test, $t=0.39$, $p=0.70)$. Moreover, Rines KO mice had increased MAO-A protein levels in the LC, as revealed by quantitative immunostaining (Fig. 6A-C: MAO-A intensity, Student's $t$ test, $t=3.49, p=0.00064$; relative intensity of MAO-A/TH, Student's $t$ test, $t=2.24, p=$ 0.0264 ). In control experiments, neither the immunostaining signal intensity for the catecholamine synthesizing enzyme TH (Fig. $6 A-C$ : TH intensity, Student's $t$ test, $t=0.76, p=0.45$ ) nor the area or number of TH-positive cells (Fig. 6D, E: relative area in LC region, Student's $t$ test, $t=1.04, p=0.30$; total cell number in LC region, Student's $t$ test, $t=0.35, p=0.73$ ) in the LC region differed between $\mathrm{WT}$ and $\mathrm{KO}$ mice. In addition, there were no intergenotype differences in the mRNA levels of MAO-A or other proteins involved in the synthesis, transport, or metabolism of monoamines (Fig. 6F: MAO-A, Student's $t$ test, $t=0.15, p=0.88$; MAO-B, Student's $t$ test, $t=0.35, p=0.73$; DBH, Student's $t$ test, $t=1.09, p=0.30$; NET, Student's $t$ test, $t=0.31, p=0.76$; VMAT2, Student's $t$ test, $t=0.20$, $p=0.84$; COMT, Student's $t$ test, $t=1.58, p=0.14$; Rines, Welch's $t$ test, $t=27.28, p<0.0001$ ). These results suggest that Rines may reduce MAO-A protein levels posttranslationally in the $\mathrm{LC}$, with a cognate reduction in MAO-A activity.

To determine the specificity and regulation of MAO-A by Rines, we investigated whether ubiquitination and subsequent degradation of MAO-A protein was mediated by Rines in cell culture. First, we verified the interaction between Rines and MAO-A. When Flag-Rines was coexpressed with HA-MAO-A in epoxomicin (a proteasome inhibitor)-treated HEK293T cells and immunoprecipitated with an anti-Flag antibody, we detected the coprecipitated HA-MAO-A (Fig. 7A). We also investigated whether Rines could promote the ubiquitination of the MAO-A protein. Flag-MAO-A and HA-ubiquitin were coexpressed in NIH3T3 cells in the presence or absence of Myc-Rines, and cell lysates were subjected to immunoprecipitation with an anti-Flag antibody, followed by immunoblotting with an anti-HA antibody to detect ubiquitin-conjugated MAO-A. As a result, MycRines enhanced a broad band with high molecular weight corresponding to polyubiquitinated Flag-MAO-A (Fig. 7B), indicating that $\mathrm{MAO}-\mathrm{A}$ was polyubiquitinated by Rines. Myc-Rines was detected in Flag-MAO-A coprecipitates (Fig. 7B), which is consistent with the results presented in Figure 7A. Furthermore, we observed that HA-MAO-A protein levels decreased in the presence of Flag-Rines and this reduction was rescued by epoxomicin treatment (Fig. 7C). In addition, we verified the ubiquitination of endogenous MAO-A by Rines in the brain LC region (Fig. 7D). Tissue lysates of the LC regions from WT or Rines KO mice were immunoprecipitated with an anti-MAO-A antibody and then immunoblotted with an anti-ubiquitin antibody to detect polyubiquitinated MAO-A protein. We determined the densities of the broad band with high molecular weight corresponding to polyubiquitinated endogenous MAO-A. The densities significantly decreased in Rines KO mice (Fig. 7D: Student's $t$ test, $t=3.42, p=0.0090$ ). Furthermore, a band corresponding to unubiquitinated MAO-A protein in Rines $\mathrm{KO}$ mice was more intense than that in WT mice (Fig. 7D: Student's $t$ test, $t=2.70, p=$ 0.027 ), a result consistent with the MAO-A immunostaining (Fig. $6 A-C)$. These results indicate that Rines promotes ubiquitination and proteasomal degradation of MAO-A both in cell culture and brain LC.

The above results suggest that the altered emotional responses in Rines $\mathrm{KO}$ mice might be at least partially due to increased MAO-A activity in the absence of Rines-dependent protein degradation. To address this possibility, we examined the effect of the nonselective and irreversible MAO inhibitor TCP on emotional responses (Fig. $8 A-E$ ). TCP is used as an antidepressant and anxiolytic agent in the clinical treatment of mood and anxiety disorders (O'Donnell and Shelton, 2010). Rines KO and WT mice were orally administered TCP or vehicle (water) chronically for 11-23 d and then tested behaviorally. In the open field test, TCP increased the number of movements in Rines KO mice and rescued behavioral function to a level comparable to control WT mice (Fig. $8 A$ : two-way ANOVA, $F_{\text {genotype }(1,91)}=8.63, p=0.0042$; $F_{\text {drug }(1,91)}=4.52, p=0.036 ; F_{\text {genotype }} \times \operatorname{drug}(1,91)=4.04, p=0.046$; WT-water vs KO-water, Student's $t$ test, $t=3.44, p=0.0012$; KO-water vs KO-TCP, Student's $t$ test, $t=2.84, p=0.0070)$. A similar tendency, although not significant, was observed in the total time spent in the center of the field in the open field test (Fig. $8 C$ : two-way ANOVA, $F_{\text {genotype }(1,91)}=2.18, p=0.14$; $\left.F_{\text {drug }(1,91)}=0.14, p=0.71 ; F_{\text {genotype } \times \operatorname{drug}(1,91)}=0.48, p=0.49\right)$ and TCP increased the total distance only in WT mice but not in KO mice (Fig. 8B: WT-water vs WT-TCP, Student's $t$ test, $t=$ $3.43, p=0.0012 ; \mathrm{KO}$-water vs KO-TCP, Student's $t$ test, $t=1.60$, $p=0.12$; two-way ANOVA, $F_{\text {genotype }(1,91)}=1.22, p=0.27$; $F_{\text {drug }(1,91)}=11.72, p=0.00093 ; F_{\text {genotype }} \times \operatorname{drug}(1,91)=0.77, p=$ 0.38 ). In addition, a two-way ANOVA demonstrated significant genotype-treatment interaction effects on the immobility time on the second day of the forced swimming test (Fig. $8 D$ : two-way ANOVA, $F_{\text {genotype }(1,131)}=0.79, p=0.37 ; F_{\text {drug }(1,131)}=$ $5.88, p=0.017 ; F_{\text {genotype }} \times \operatorname{drug}(1,131)=4.04, p=0.047 ; \mathrm{WT}-$ water vs WT-TCP, Student's $t$ test, $t=3.35, p=0.0013$; 
A
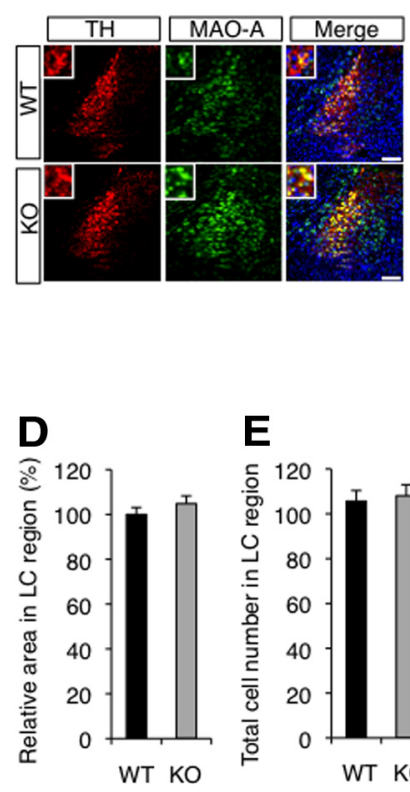
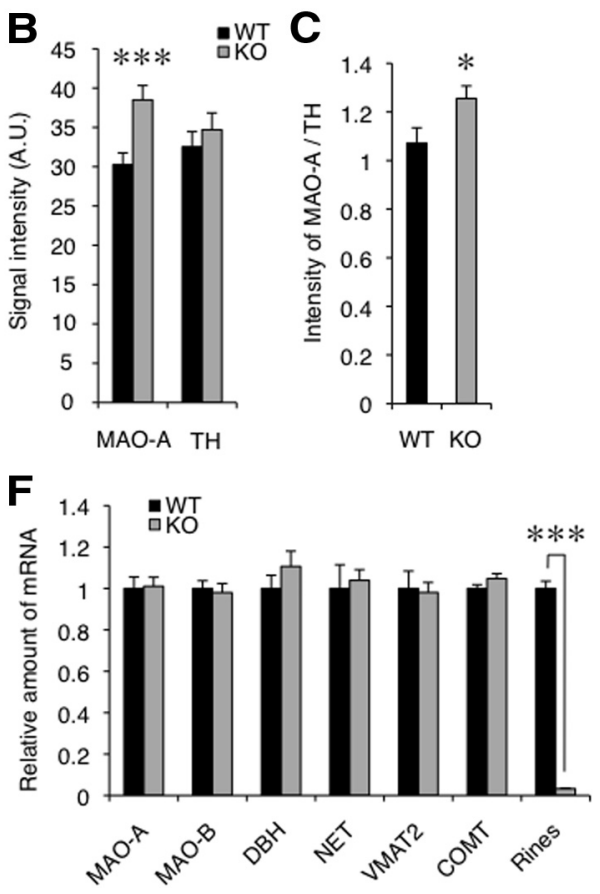

Figure 6. Rines regulated MAO-A protein level. $\boldsymbol{A}-\boldsymbol{C}$, Rines KO mice showed significantly increased MAO-A protein levels in the $\mathrm{LC}$ region. $\boldsymbol{A}$, Representative immunofluorescence staining of TH and $\mathrm{MAO}-\mathrm{A}$ proteins in the $\mathrm{LC}$ region from WT and Rines $\mathrm{KO}$ mice. High-magnification images of the center regions are shown in insets. WT, $n=5 ; \mathrm{KO}, n=5$. Scale bar, $100 \mu \mathrm{m}$. $\boldsymbol{B}$, Quantitative analyses of signal intensities for MAO-A and TH. ${ }^{* * *} p<0.001$, Student's $t$ test. AU, arbitrary unit. C, Intensities of MA0-A relative to TH. ${ }^{* *} p<0.01$, Student's $t$ test. $\boldsymbol{D}, \boldsymbol{E}$, Comparison of the areas and total cell numbers in the $L C$ regions of WT and Rines $\mathrm{KO}$ mice. There were no significant differences in the area $(\boldsymbol{D})$ or number $(\boldsymbol{E})$ of TH-expressing cells in the LC region between the two genotypes. WT mean values $=100 \%$ (D). WT, $n=5 ; \mathrm{KO}, n=5$. $\boldsymbol{F}$, The relative amount of $\mathrm{mRNA}$ in the LC region isolated from WT and Rines KO mice measured with quantitative RT-PCR. DBH, dopamine $\beta$-hydroxylase; NET, NE transporter; VMAT2, vesicular monoamine transporter protein 2; COMT, catechol-0-methyltransferase. No differences were detected in the mRNA levels of these proteins between the genotypes. WT, $n=7 ; \mathrm{K} 0, n=7 ;{ }^{* * *} p<0.001$, Welch's $t$ test. WT values are indicated as 1 .

WT-TCP vs KO-TCP, Student's $t$ test, $t=2.08, p=0.042)$ and the latency to enter the dark box in the light-dark box test (Fig. $8 E$ : two-way ANOVA, $F_{\text {genotype }(1,131)}=0.012, p=0.91 ; F_{\text {drug }(1,131)},<$ $\left.0.0001, p=0.999 ; F_{\text {genotype }} \times \operatorname{drug}(1,131)=4.17, p=0.043\right)$. In addition, we examined the effect of a specific MAO-A inhibitor, clorgyline, on emotional memory formation in the passive avoidance test (Fig. $8 F$ ). Two and a half hours after the intraperitoneal administration of clorgyline or vehicle (saline), mice were conditioned with an electric foot shock (Fig. 3C). In a test performed $24 \mathrm{~h}$ later, clorgyline-treated $\mathrm{KO}$ mice exhibited significantly lower latencies than did saline-treated $\mathrm{KO}$ mice, although there were no significant differences between saline-treated and clorgyline-treated WT mice (Fig. 8F: WT-saline vs WT-clorgyline, Student's $t$ test, $t=0.25, p=$ $0.81 ; \mathrm{KO}$-saline vs KO-clorgyline, Student's $t$ test, $t=2.78, p=$ 0.011 ; WT-saline vs KO-saline, Student's $t$ test, $t=2.08, p=0.049$; WT-clorgyline vs KO-clorgyline, Welch's $t$ test, $t=3.57, p=$ $0.0028)$. The differential response to TCP or clorgyline in these emotional behaviors supports the idea that Rines is involved in MAO-A proteostasis in connection with some emotional responses.

\section{Discussion}

\section{Rines controls emotional and social behaviors}

Rines KO mice exhibited several types of abnormal responses to environmental changes and social inputs. First, they showed enhanced anxiety-like behaviors in response to exposure to new and unexpected nonpainful sensory stimuli (i.e., open space in the open field test, open arms in the elevated plus maze test, Fig. $3 A, B$ ). Second, altered stress reactivity was indicated by the exposure to aver- sive stimuli over two successive days (the passive avoidance and forced swimming tests, Fig. 3C,D). Second-day responses were similar to those on the first day, whereas these two responses were significantly different in WT mice. Third, affiliative social behaviors increased in both familiar and unfamiliar environments (the social interaction and resident-intruder tests, Fig. 4A,B). Therefore, Rines KO mice, which show altered reactivity to new stimuli, would be interesting model animals to investigate the molecular mechanisms underlying proper emotional and social behaviors.

\section{Rines regulates monoamine levels in the brain}

This study shows that Rines KO mice have altered monoamine levels in some brain regions. Among the three major monoamine sources (LC, raphe nuclei, and substantia nigra), significantly less NE and 5-HT were observed in the LC after aversive stimuli (Table 2). Exposure to new, unexpected, or non-noxious stimuli activates the rodent LC (Aston-Jones and Bloom, 1981). Acute emotional responses, including activation of fear memories and stress responses, involve activation of LC neurons (Berridge and Waterhouse, 2003; Alsene and Bakshi, 2011).

Consistent with this idea, studies in humans and primates demonstrate that LC-NE neurotransmission plays a vital role in cognitive and attentional processes (Berridge and Waterhouse, 2003; van Stegeren, 2008; Kindt et al., 2009). Dysregulation of this system contributes to cognitive and emotional dysfunction associated with a variety of psychiatric disorders, including stress- and/or anxiety-related disorders (Berridge and Waterhouse, 2003; van Stegeren, 2008; Kindt et al., 2009; Alsene and Bakshi, 2011).

In addition to LC monoamines, lower 5-HT levels observed in the prefrontal cortex are intriguing in view of the following points. First, the serotonergic system has been reported to play an important role in the prefrontal cortex, a major area regulating emotion and cognition (Barnes and Sharp, 1999; Gross et al., 2002; Weisstaub et al., 2006; Meltzer and Huang, 2008; Puig and Gulledge, 2011). In rodents, intraprefrontal cortex administration of a 5-HT1A or 5-HT1B agonist-antagonist alters the amount of time in the open arms of an elevated plus maze (Solati et al., 2011), and disruption of 5-HT2A receptor signaling in cerebral cortex affects the time spent in the center of an open field (Weisstaub et al., 2006). The anxiety-like behavior in the Rines KO mice could reflect altered 5-HT levels in the prefrontal cortex. Second, 5-HT levels in the Rines KO prefrontal cortex is reciprocally altered upon exposure to foot shock stress compared with WT (Table 2). This indicates the altered stress reactivity of the Rines KO brain, which could be the basis of the abnormalities in the forced swimming and passive avoidance tests. Third, the 5-HT system is involved in controlling aggressive behaviors in mice (Saudou et al., 1994; Korte et al., 1996; Popova et al., 1996; Popova, 2008). The altered social behavior in Rines KO mice could also be related to the 5-HT dysregulation. 
We also observed that NE levels increased in the stressed prefrontal cortex and unstressed amygdala of Rines $\mathrm{KO}$ mice (Table 2). Considering that the NE fibers from the LC have auto-NE receptors that inhibit NE release (Starke, 2001), the reduction of NE in the LC might lead to impaired NE feedback, thus increasing the apparent levels of $\mathrm{NE}$ in the prefrontal cortex and amygdala. Similar observations have been reported in the brain of SIRT1overexpressing mice. These mice showed higher MAO-A activity and lower 5-HT levels in their brain regions than WT mice. However, in contrast to 5-HT, they showed higher NE levels than those of WT mice (Libert et al., 2011).

Rines is a critical regulator of the MAOA protein level

We have shown that MAO-A activity and protein abundance increases in the $\mathrm{LC}$ region of Rines $\mathrm{KO}$ mice (Figs. 5, 6A-C, $7 D)$. Furthermore, Rines can bind and ubiquitinate $\mathrm{MAO}-\mathrm{A}$ and can enhance its proteosomal degradation (Fig. 7). The ubiquitination of endogenous MAO-A by Rines was verified by the ubiquitination assay using the LC regions from WT and Rines KO mice. The polyubiquitination of MAO-A in the LC region decreased in Rines $\mathrm{KO}$ mice (Fig. $7 D$ ). In addition, part of the behavioral phenotype of the Rines KO was the opposite of that of the MAO-A loss-of-function mutant mice; that is, MAO-A KO mice exhibit emotional behavior abnormalities including increased time spent in the center of the platform in the open field test (Cases et al., 1995) and enhanced fear conditioning in the passive avoidance test (Kim et al., 1997; Dubrovina et al., 2006). Furthermore, social investigation and interaction are reduced in both MAO-A-KO and MAOA-hypomorphic mice (Cases et al., 1995; Vishnivetskaya et al., 2007; Scott et al., 2008; Bortolato et al., 2011).

These behavioral and monoamine abnormalities in Rines KO mice and our biochemical analysis suggest that Rines regulates $\mathrm{MAO}-\mathrm{A}$ protein levels in specific brain regions. The basis of the selective MAO-A deregulation in LC (Fig. 5) remains to be elucidated. We surmise that the altered protein degradation rate might be most easily detected in LC with the highest MAO-A expression. Otherwise, other factors cooperating with or targeted by Rines might be differentially distributed in the brain regions. However, the distinct response of MAO inhibitors on some Rines KO behaviors supports the idea that the control of emotional behavior by Rines is partly due to the deregulation of brain MAO-A subset (Fig. 8).

MAO-A expression is known to be transcriptionally regulated (Chen et al., 2005; Libert et al., 2011). However, this study is the
B

\begin{tabular}{lllll} 
& \multicolumn{3}{c}{ Epoxomicin } \\
\hline HA-Ub & + & + & + & + \\
Flag-MAO-A & - & - & + & + \\
Myc-Rines & - & + & - & + \\
Flag-vector & + & + & - & - \\
Myc-vector & + & - & + & - \\
\hline
\end{tabular}

C
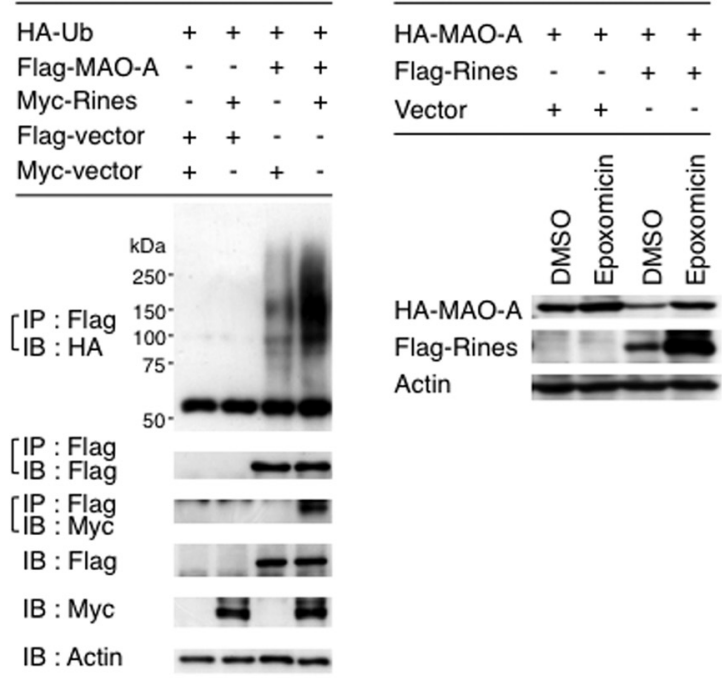

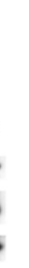

Figure 7. Rines promotes the ubiquitination and degradation of $M A O-A$ in the proteasome. $A$, Coimmunoprecipitation of the Rines protein with MA0-A protein from HEK293T cells transfected with Rines and MA0-A expression vectors and treated with a ( Ubiquitination of endogenous MAO-A in LC decreased in Rines KO mice. Left: Equal protein amounts of tissue of $\mathrm{LC}$ region from WT or Rines KO mice were immunoprecipitated with an anti-MA0-A antibody and then immunoblotted (I) to detect polyubiquitinated endogenous MA0-A (apparent as smear bands) or were directly with anti-MA0-A antibody (input). Middle: Intensities of polyubiquitinated MA0-A relative to that of unubiquitinated MA0-A. ${ }^{* *} p<0.01$, Student's $t$ test. WT, $n=5 ; \mathrm{KO}, n=5$. Right: Intensities of unubiquitinated MA0-A in LC regions of WT and Rines $\mathrm{KO}$ mice. Endogenous MAO-A protein levels in $\mathrm{LC}$ region from Rines $\mathrm{KO}$ mice increased relative to those from WT mice. $\mathrm{WT}, n=5 ; \mathrm{KO}, n=5 ;{ }^{*} p<0.05$, Student's $t$ test. WT values are indicated as 1.

first to reveal the regulation of MAO-A protein level via the UPS. It is likely that MAO-A levels are controlled both at the level of gene expression and proteasomal degradation, and the balance between anabolism and catabolism finely tunes the optimal amount. Although the UPS is proposed to be involved in mood disorder pathogenesis based on genome-wide association and gene expression analyses (Ryan et al., 2006; Garriock et al., 2010; Gormanns et al., 2011), little is known of the E3 ubiquitin ligase that plays a role in affective behaviors by alteration of the monoaminergic system. In addition, to our knowledge, no studies have found that the E3 ubiquitin ligase targets monoamine-metabolizing enzymes. Considering the role of the monoamine system in controlling overall brain functions (Bear et al., 2006), our Rines KO mice may become an important animal model for understanding the molecular 


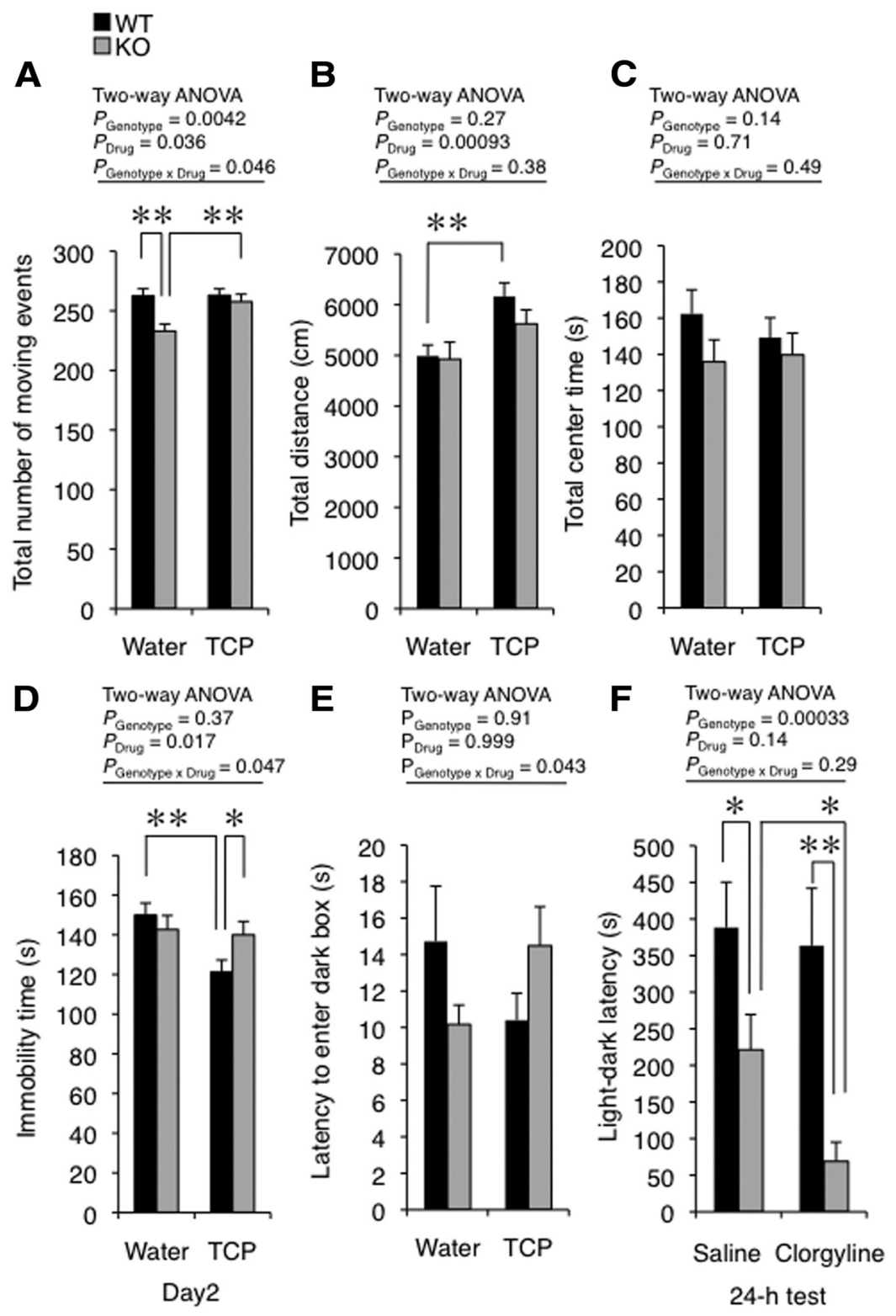

Figure 8. Emotional behaviors in Rines KO and WT mice were differentially affected by MAO inhibitors. $\boldsymbol{A}-\boldsymbol{E}$, Water or water containing the MAO inhibitor TCP (3 mg/kg) was administered to mice chronically. The total number of movements $(\boldsymbol{A})$, total distance $(\boldsymbol{B})$, and total center time $(\boldsymbol{C})$ in the open field test were measured. $\boldsymbol{A}$, TCP rescued the reduction in the total number of movements in KO mice. $\boldsymbol{D}, \boldsymbol{E}$, Rines KO mice exhibited altered responses to TCP in the immobility time on the second day of the forced swimming test $(\boldsymbol{D})$ and the latency to enter dark box in the light-dark box test $(\boldsymbol{E}) . n=22-25$ mice per condition in the open field test; $n=32-36$ mice per condition in the forced swimming test; $n=32-36$ mice per condition in the light- dark box test; ${ }^{*} p<0.05,{ }^{* *} p<0.01$, Student's $t$ test. $\boldsymbol{F}$, Saline or the selective MA0-A inhibitor clorgyline $(0.1-1 \mathrm{mg} / \mathrm{kg})$ was intraperitoneally administered to mice $2.5 \mathrm{~h}$ before electric foot shock on the conditioning day in passive avoidance test. Data are presented as light-dark latencies in the $24 \mathrm{~h}$ test. Rines $\mathrm{K} 0$ mice showed a distinct response to the clorgyline. $n=12-14$ mice per condition; ${ }^{*} p<0.05,{ }^{* *} p<0.01$, Student's $t$ test or Welch's $t$ test.

mechanisms underlying the regulation of emotional responses and social behaviors.

\section{Clinical implications of Rines-}

mediated regulation of the monoaminergic pathway

Abnormalities evident in Rines KO mice may have clinical implications. Interestingly, MAO-A-H (the higher transcriptional efficiency variant) is associated with anxiety and mood disorders (Deckert et al., 1999; Schulze et al., 2000; Samochowiec et al., 2004; Yu et al., 2005; Meyer et al., 2006). We speculate that the pathophysiological status of patients is related to the enhanced anxiety and altered stress reactivity in Rines KO mice. Furthermore, the MAO-A level in human brain is inversely correlated with the personality traits of aggression (Alia-Klein et al., 2008). The contrasting sociality between Rines $\mathrm{KO}$ mice (highly affiliative behaviors) and MAO-A KO hypomorphic mice (low affiliative behaviors) may reflect the difference in MAO-A activity (Rines KO, high; MAO-A mutants, low). In sum, the Rines $\mathrm{KO}$ behavioral phenotypes found in this study may be linked to MAO-A activity.

Consistent with this view, a recent study showed that SIRT1 activates transcription of MAO-A, and transgenic mice overexpressing SIRT1 in the brain show enhanced anxiety-like behavior (Libert et al., 2011). Moreover, SIRT1 variants are associated with risk of anxiety in human population samples (Libert et al., 2011), providing evidence that a protein that regulates MAO-A levels can be a diseasecausing factor.

In contrast, studies on human subjects indicate that the prevalence of aggressive and antisocial behavior in adults in the MAO-A-L (the lower transcriptional efficiency variant) is affected by their history of stress during childhood, such as abuse and maltreatment (Caspi et al., 2002; Kim-Cohen et al., 2006). In addition, administration of a 5-HT synthesis inhibitor to MAOA-KO mice during brain development (postnatal days $0-6$ ) reverses aggressive behavior in adulthood (Cases et al., 1996). Therefore, emotional behavior abnormalities in Rines $\mathrm{KO}$ mice may be affected by age and environmental factors. Longitudinal and gene-environment interaction studies with Rines $\mathrm{KO}$ mice would contribute to a more comprehensive understanding of the pathophysiology of aggression and antisocial behavior.

Finally, Rines is the first reported E3 ubiquitin ligase the deletion of which causes altered MAO-A levels in the LC, monoamine levels in some brain regions, and emotional behaviors including social behavior. Further clarification of the role of this enzyme in emotional responses along with genetic analyses of human Rines polymorphisms should offer new insights into psychiatry and the treatment of anxiety, stress-related disorders, and impaired social functions.

\section{References}

Alia-Klein N, Goldstein RZ, Kriplani A, Logan J, Tomasi D, Williams B, Telang F, Shumay E, Biegon A, Craig IW, Henn F, Wang GJ, Volkow ND, Fowler JS (2008) Brain monoamine oxidase A activity predicts trait aggression. J Neurosci 28:5099-5104. CrossRef Medline

Alsene KM, Bakshi VP (2011) Pharmacological stimulation of locus coeruleus reveals a new antipsychotic-responsive pathway for deficient senso- 
rimotor gating. Neuropsychopharmacology 36:1656-1667. CrossRef Medline

Aston-Jones G, Bloom FE (1981) Norepinephrine-containing locus coeruleus neurons in behaving rats exhibit pronounced responses to nonnoxious environmental stimuli. J Neurosci 1:887-900. Medline

Barnes NM, Sharp T (1999) A review of central 5-HT receptors and their function. Neuropharmacology 38:1083-1152. CrossRef Medline

Bear MF, Conors BW, Paradiso MA (2006) Neuroscience, exploring the brain, Ed 3. Philadelphia: Lippincott Williams \& Wilkins.

Berridge CW, Waterhouse BD (2003) The locus coeruleus-noradrenergic system: modulation of behavioral state and state-dependent cognitive processes. Brain Res Brain Res Rev 42:33-84. CrossRef Medline

Bortolato M, Chen K, Shih JC (2008) Monoamine oxidase inactivation: from pathophysiology to therapeutics. Adv Drug Deliv Rev 60:15271533. CrossRef Medline

Bortolato M, Chen K, Godar SC, Chen G, Wu W, Rebrin I, Farrell MR, Scott AL, Wellman CL, Shih JC (2011) Social deficits and perseverative behaviors, but not overt aggression, in MAO-A hypomorphic mice. Neuropsychopharmacology 36:2674-2688. CrossRef Medline

Brunner HG, Nelen M, Breakefield XO, Ropers HH, van Oost BA (1993) Abnormal behavior associated with a point mutation in the structural gene for monoamine oxidase A. Science 262:578-580. CrossRef Medline

Carninci P, Kasukawa T, Katayama S, Gough J, Frith MC, Maeda N, Oyama R, Ravasi T, Lenhard B, Wells C, Kodzius R, Shimokawa K, Bajic VB, Brenner SE, Batalov S, Forrest AR, Zavolan M, Davis MJ, Wilming LG, Aidinis V, et al.; FANTOM Consortium; RIKEN Genome Exploration Research Group and Genome Science Group (Genome Network Project Core Group) (2005) The transcriptional landscape of the mammalian genome. Science 309:1559-1563. CrossRef Medline

Cases O, Seif I, Grimsby J, Gaspar P, Chen K, Pournin S, Müller U, Aguet M, Babinet C, Shih JC, et al. (1995) Aggressive behavior and altered amounts of brain serotonin and norepinephrine in mice lacking MAOA. Science 268:1763-1766. CrossRef Medline

Cases O, Vitalis T, Seif I, De Maeyer E, Sotelo C, Gaspar P (1996) Lack of barrels in the somatosensory cortex of monoamine oxidase A-deficient mice: role of a serotonin excess during the critical period. Neuron 16:297307. CrossRef Medline

Caspi A, McClay J, Moffitt TE, Mill J, Martin J, Craig IW, Taylor A, Poulton R (2002) Role of genotype in the cycle of violence in maltreated children. Science 297:851-854. CrossRef Medline

Chen K, Ou XM, Chen G, Choi SH, Shih JC (2005) R1, a novel repressor of the human monoamine oxidase A. J Biol Chem 280:11552-11559. CrossRef Medline

Deckert J, Catalano M, Syagailo YV, Bosi M, Okladnova O, Di Bella D, Nöthen MM, Maffei P, Franke P, Fritze J, Maier W, Propping P, Beckmann H, Bellodi L, Lesch KP (1999) Excess of high activity monoamine oxidase A gene promoter alleles in female patients with panic disorder. Hum Mol Genet 8:621-624. CrossRef Medline

Dubrovina NI, Popova NK, Gilinskii MA, Tomilenko RA, Seif I (2006) Acquisition and extinction of a conditioned passive avoidance reflex in mice with genetic knockout of monoamine oxidase A. Neurosci Behav Physiol 36:335-339. CrossRef Medline

Duncan GE, Johnson KB, Breese GR (1993) Topographic patterns of brain activity in response to swim stress: assessment by 2-deoxyglucose uptake and expression of Fos-like immunoreactivity. J Neurosci 13:3932-3943. Medline

Garriock HA, Kraft JB, Shyn SI, Peters EJ, Yokoyama JS, Jenkins GD, Reinalda MS, Slager SL, McGrath PJ, Hamilton SP (2010) A genomewide association study of citalopram response in major depressive disorder. Biol Psychiatry 67:133-138. CrossRef Medline

Gong B, Cao Z, Zheng P, Vitolo OV, Liu S, Staniszewski A, Moolman D, Zhang H, Shelanski M, Arancio O (2006) Ubiquitin hydrolase Uch-L1 rescues beta-amyloid-induced decreases in synaptic function and contextual memory. Cell 126:775-788. CrossRef Medline

Gormanns P, Mueller NS, Ditzen C, Wolf S, Holsboer F, Turck CW (2011) Phenome-transcriptome correlation unravels anxiety and depression related pathways. J Psychiatr Res 45:973-979. CrossRef Medline

Gross C, Zhuang X, Stark K, Ramboz S, Oosting R, Kirby L, Santarelli L, Beck S, Hen R (2002) Serotonin1A receptor acts during development to establish normal anxiety-like behaviour in the adult. Nature 416: 396-400. CrossRef Medline
Hershko A, Ciechanover A (1998) The ubiquitin system. Annu Rev Biochem 67:425-479. CrossRef Medline

Hunter P (2010) The psycho gene. EMBO Rep 11:667-669. CrossRef Medline

Inoue T, Hatayama M, Tohmonda T, Itohara S, Aruga J, Mikoshiba K (2004) Mouse Zic5 deficiency results in neural tube defects and hypoplasia of cephalic neural crest derivatives. Dev Biol 270:146-162. CrossRef Medline

Irie F, Badie-Mahdavi H, Yamaguchi Y (2012) Autism-like sociocommunicative deficits and stereotypies in mice lacking heparan sulfate. Proc Natl Acad Sci U S A 109:5052-5056. CrossRef Medline

Jiang H, Jiang Q, Liu W, Feng J (2006) Parkin suppresses the expression of monoamine oxidases. J Biol Chem 281:8591-8599. CrossRef Medline

Johnston JA, Madura K (2004) Rings, chains and ladders: ubiquitin goes to work in the neuron. Prog Neurobiol 73:227-257. CrossRef Medline

Katayama K, Yamada K, Ornthanalai VG, Inoue T, Ota M, Murphy NP, Aruga J (2010) Slitrk1-deficient mice display elevated anxiety-like behavior and noradrenergic abnormalities. Mol Psychiatry 15:177184. CrossRef Medline

Kato T, Ishiwata M, Yamada K, Kasahara T, Kakiuchi C, Iwamoto K, Kawamura K, Ishihara H, Oka Y (2008) Behavioral and gene expression analyses of Wfs1 knockout mice as a possible animal model of mood disorder. Neurosci Res 61:143-158. CrossRef Medline

Kawabe H, Neeb A, Dimova K, Young SM Jr, Takeda M, Katsurabayashi S, Mitkovski M, Malakhova OA, Zhang DE, Umikawa M, Kariya K, Goebbels S, Nave KA, Rosenmund C, Jahn O, Rhee J, Brose N (2010) Regulation of Rap2A by the ubiquitin ligase Nedd4-1 controls neurite development. Neuron 65:358-372. CrossRef Medline

Kim JJ, Shih JC, Chen K, Chen L, Bao S, Maren S, Anagnostaras SG, Fanselow MS, De Maeyer E, Seif I, Thompson RF (1997) Selective enhancement of emotional, but not motor, learning in monoamine oxidase A-deficient mice. Proc Natl Acad Sci U S A 94:5929-5933. CrossRef Medline

Kim-Cohen J, Caspi A, Taylor A, Williams B, Newcombe R, Craig IW, Moffitt TE (2006) MAOA, maltreatment, and gene-environment interaction predicting children's mental health: new evidence and a meta-analysis. Mol Psychiatry 11:903-913. CrossRef Medline

Kindt M, Soeter M, Vervliet B (2009) Beyond extinction: erasing human fear responses and preventing the return of fear. Nat Neurosci 12:256258. CrossRef Medline

Kitanaka N, Kitanaka J, Takemura M (2006) Modification of morphineinduced hyperlocomotion and antinociception in mice by clorgyline, a monoamine oxidase-A inhibitor. Neurochem Res 31:829-837. CrossRef Medline

Koen N, Stein DJ (2011) Pharmacotherapy of anxiety disorders: a critical review. Dialogues Clin Neurosci 13:423-437. Medline

Korte SM, Meijer OC, de Kloet ER, Buwalda B, Keijser J, Sluyter F, van Oortmerssen G, Bohus B (1996) Enhanced 5-HT1A receptor expression in forebrain regions of aggressive house mice. Brain Res 736:338343. CrossRef Medline

Lee SH, Choi JH, Lee N, Lee HR, Kim JI, Yu NK, Choi SL, Lee SH, Kim H, Kaang BK (2008) Synaptic protein degradation underlies destabilization of retrieved fear memory. Science 319:1253-1256. CrossRef Medline

Libert S, Pointer K, Bell EL, Das A, Cohen DE, Asara JM, Kapur K, Bergmann S, Preisig M, Otowa T, Kendler KS, Chen X, Hettema JM, van den Oord EJ, Rubio JP, Guarente L (2011) SIRT1 activates MAO-A in the brain to mediate anxiety and exploratory drive. Cell 147:1459-1472. CrossRef Medline

Maki Y, Inoue T, Izumi T, Muraki I, Ito K, Kitaichi Y, Li X, Koyama T (2000) Monoamine oxidase inhibitors reduce conditioned fear stress-induced freezing behavior in rats. Eur J Pharmacol 406:411-418. CrossRef Medline

Meltzer HY, Huang M (2008) In vivo actions of atypical antipsychotic drug on serotonergic and dopaminergic systems. Prog Brain Res 172: 177-197. CrossRef Medline

Meyer JH, Ginovart N, Boovariwala A, Sagrati S, Hussey D, Garcia A, Young T, Praschak-Rieder N, Wilson AA, Houle S (2006) Elevated monoamine oxidase a levels in the brain: an explanation for the monoamine imbalance of major depression. Arch Gen Psychiatry 63:1209-1216. CrossRef Medline

Millan MJ (2003) The neurobiology and control of anxious states. Prog Neurobiol 70:83-244. CrossRef Medline

Moriyoshi K, Iijima K, Fujii H, Ito H, Cho Y, Nakanishi S (2004) Seven in 
absentia homolog 1A mediates ubiquitination and degradation of group 1 metabotropic glutamate receptors. Proc Natl Acad Sci U S A 101:86148619. CrossRef Medline

O'Donnell JM, Shelton RC (2010) Drug therapy of depression and anxiety disorders. In: Goodman and Gilman's the pharmacological basis of therapeutics, Ed 12 (Brunton LL, ed), pp 397-415. New York: McGraw-Hill.

Ogawa M, Mizugishi K, Ishiguro A, Koyabu Y, Imai Y, Takahashi R, Mikoshiba K, Aruga J (2008) Rines/RNF180, a novel RING finger geneencoded product, is a membrane-bound ubiquitin ligase. Genes Cells 13:397-409. CrossRef Medline

Pickart CM (2001) Mechanisms underlying ubiquitination. Annu Rev Biochem 70:503-533. CrossRef Medline

Popova NK (2008) From gene to aggressive behavior: the role of brain serotonin. Neurosci Behav Physiol 38:471-475. CrossRef Medline

Popova NK, Kulikov AV, Avgustinovich DF, Shigantsov SN (1996) The characteristics of the brain serotonin system and anxiety in the C57BL and CBA mouse strains [Article in Russian]. Zh Vyssh Nerv Deiat Im I P Pavlova 46:348-354. Medline

Porsolt RD, Anton G, Blavet N, Jalfre M (1978) Behavioural despair in rats: a new model sensitive to antidepressant treatments. Eur J Pharmacol 47:379-391. CrossRef Medline

Porsolt RD, Bertin A, Blavet N, Deniel M, Jalfre M (1979) Immobility induced by forced swimming in rats: effects of agents which modify central catecholamine and serotonin activity. Eur J Pharmacol 57:201210. CrossRef Medline

Puig MV, Gulledge AT (2011) Serotonin and prefrontal cortex function: neurons, networks, and circuits. Mol Neurobiol 44:449-464. CrossRef Medline

Ravindran LN, Stein MB (2010) The pharmacologic treatment of anxiety disorders: a review of progress. J Clin Psychiatry 71:839-854. CrossRef Medline

Ryan MM, Lockstone HE, Huffaker SJ, Wayland MT, Webster MJ, Bahn S (2006) Gene expression analysis of bipolar disorder reveals downregulation of the ubiquitin cycle and alterations in synaptic genes. Mol Psychiatry 11:965-978. CrossRef Medline

Sakatani S, Yamada K, Homma C, Munesue S, Yamamoto Y, Yamamoto H, Hirase H (2009) Deletion of RAGE causes hyperactivity and increased sensitivity to auditory stimuli in mice. PLoS One 4:e8309. CrossRef Medline

Sakurai M, Sekiguchi M, Zushida K, Yamada K, Nagamine S, Kabuta T, Wada $\mathrm{K}$ (2008) Reduction in memory in passive avoidance learning, exploratory behaviour and synaptic plasticity in mice with a spontaneous deletion in the ubiquitin C-terminal hydrolase L1 gene. Eur J Neurosci 27: 691-701. CrossRef Medline

Samochowiec J, Hajduk A, Samochowiec A, Horodnicki J, Stepién G, Grzywacz A, Kucharska-Mazur J (2004) Association studies of MAO-A, COMT, and 5-HTT genes polymorphisms in patients with anxiety disorders of the phobic spectrum. Psychiatry Res 128:21-26. CrossRef Medline

Satoh Y, Endo S, Ikeda T, Yamada K, Ito M, Kuroki M, Hiramoto T, Imamura O, Kobayashi Y, Watanabe Y, Itohara S, Takishima K (2007) Extracellu- lar signal-regulated kinase 2 (ERK2) knockdown mice show deficits in long-term memory; ERK2 has a specific function in learning and memory. J Neurosci 27:10765-10776. CrossRef Medline

Saudou F, Amara DA, Dierich A, LeMeur M, Ramboz S, Segu L, Buhot MC, Hen R (1994) Enhanced aggressive behavior in mice lacking 5-HT1B receptor. Science 265:1875-1878. CrossRef Medline

Schulze TG, Müller DJ, Krauss H, Scherk H, Ohlraun S, Syagailo YV, Windemuth C, Neidt H, Grässle M, Papassotiropoulos A, Heun R, Nöthen MM, Maier W, Lesch KP, Rietschel M (2000) Association between a functional polymorphism in the monoamine oxidase A gene promoter and major depressive disorder. Am J Med Genet 96:801-803. CrossRef Medline

Scott AL, Bortolato M, Chen K, Shih JC (2008) Novel monoamine oxidase A knock out mice with human-like spontaneous mutation. Neuroreport 19:739-743. CrossRef Medline

Shih JC, Chen K, Ridd MJ (1999) Monoamine oxidase: from genes to behavior. Annu Rev Neurosci 22:197-217. CrossRef Medline

Solati J, Salari AA, Bakhtiari A (2011) 5HT(1A) and 5HT(1B) receptors of medial prefrontal cortex modulate anxiogenic-like behaviors in rats. Neurosci Lett 504:325-329. CrossRef Medline

Starke K (2001) Presynaptic autoreceptors in the third decade: focus on alpha2-adrenoceptors. J Neurochem 78:685-693. CrossRef Medline

Swiergiel AH, Leskov IL, Dunn AJ (2008) Effects of chronic and acute stressors and CRF on depression-like behavior in mice. Behav Brain Res 186: 32-40. CrossRef Medline

van Stegeren AH (2008) The role of the noradrenergic system in emotional memory. Acta Psychol (Amst) 127:532-541. CrossRef Medline

Vishnivetskaya GB, Skrinskaya JA, Seif I, Popova NK (2007) Effect of MAO A deficiency on different kinds of aggression and social investigation in mice. Aggress Behav 33:1-6. CrossRef Medline

Weber M, Talmon S, Schulze I, Boeddinghaus C, Gross G, Schoemaker H, Wicke KM (2009) Running wheel activity is sensitive to acute treatment with selective inhibitors for either serotonin or norepinephrine reuptake. Psychopharmacology (Berl) 203:753-762. CrossRef Medline

Weisstaub NV, Zhou M, Lira A, Lambe E, González-Maeso J, Hornung JP, Sibille E, Underwood M, Itohara S, Dauer WT, Ansorge MS, Morelli E, Mann JJ, Toth M, Aghajanian G, Sealfon SC, Hen R, Gingrich JA (2006) Cortical 5-HT2A receptor signaling modulates anxiety-like behaviors in mice. Science 313:536-540. CrossRef Medline

Yamada K, Santo-Yamada Y, Wada K (2003) Stress-induced impairment of inhibitory avoidance learning in female neuromedin $\mathrm{B}$ receptor-deficient mice. Physiol Behav 78:303-309. CrossRef Medline

Yao I, Takagi H, Ageta H, Kahyo T, Sato S, Hatanaka K, Fukuda Y, Chiba T, Morone N, Yuasa S, Inokuchi K, Ohtsuka T, Macgregor GR, Tanaka K, Setou M (2007) SCRAPPER-dependent ubiquitination of active zone protein RIM1 regulates synaptic vesicle release. Cell 130:943-957. CrossRef Medline

Yu YW, Tsai SJ, Hong CJ, Chen TJ, Chen MC, Yang CW (2005) Association study of a monoamine oxidase a gene promoter polymorphism with major depressive disorder and antidepressant response. Neuropsychopharmacology 30:1719-1723. CrossRef Medline 